\title{
A State-of-the-Art Review on the Drive of Renewables in Gujarat, State of India: Present Situation, Barriers and Future Initiatives
}

\author{
Rajvikram Madurai Elavarasan ${ }^{1, *}$,, G. M. Shafiullah ${ }^{2, *} \mathbb{(}$, Nallapaneni Manoj Kumar ${ }^{3,4}(\mathbb{D}$ and \\ Sanjeevikumar Padmanaban ${ }^{5}$ (i) \\ 1 Department of Electrical and Electronics Engineering, Sri Venkateswara College of Engineering, \\ Chennai 602117, India \\ 2 Discipline of Engineering and Energy, Murdoch University, 90 South St, Murdoch, WA 6150, Australia \\ 3 School of Energy and Environment, City University of Hong Kong, Kowloon, Hong Kong, China; \\ nallapanenichow@gmail.com or mnallapan2-c@my.cityu.edu.hk \\ 4 Sustainable Solutionz, New \#42, Old \#51, 3rd Floor, Thirumalai Pillai Road, T Nagar, Chennai 600017, India \\ 5 Department of Energy Technology, Aalborg University, 6700 Esbjerg, Denmark; san@et.aau.dk \\ * Correspondence: rajvikram787@gmail.com or rajvikram@svce.ac.in (R.M.E.); \\ gm.shafiullah@murdoch.edu.au (G.M.S.)
}

Received: 31 October 2019; Accepted: 17 December 2019; Published: 19 December 2019

\begin{abstract}
Given the recent increasing public focus on climate change issues, the share of electricity generation by renewable energy resources is increasing day by day. Increased renewables share will give us robust, sustainable, and climate-friendly energy systems for the future. Renewable energy penetration with the current power systems needs substantial research, planning and development which are now the primary focus throughout the world. In this study, a global renewable energy scenario is explained in detail in contrast with India, considering a case study elucidating the comprehensive review of the Gujarat state in India. The primary focus is on Gujarat state's actions plans to pertain to harvest renewable energy and maximizing its share in the energy mix. This study examines the actions and the policies adopted by the Gujarat government to overcome the potential barriers in order to support non-conventional as well as renewable energy development. It also investigates the numerous techno-economic and social constraints with possible solutions in promoting the deployment of upcoming renewable energy resources across Gujarat. This study can be used as a guideline for the government, policymakers, utilities, stakeholders and researchers to promote an increased renewable energy share in Gujarat as well as at other places around the globe.
\end{abstract}

Keywords: Renewable Energy (RE); energy policy; RE prospects in India; RE current scenarios; RE policy; RE barriers in India; India's most solar-powered state; Gujarat energy initiatives; lessons learned from renewables; renewables recommendation in India

\section{Introduction}

Current practices of power generation, transmission, and distribution can be considered as a prime cause of climate change effects. At present, the use of fossil fuels for power generation accounts for more than $75 \%$. Carbon dioxide is a major source of greenhouse gas and the energy sector produces nearly $75 \%$ of the total carbon dioxide emission across the globe [1]. Moreover, the statistics reveal that approximately 1.2 billion people across the globe do not have access to electricity [2,3]. Statistics account for "over 50 million people in Africa and 300 million people in India" [2,3]. A reliable, naturally available, and climate-friendly renewable energy integrated power system is, therefore, an essential global need today. The United Nations Development Program (UNDP) established Sustainable 
Development Goals (SDGs) in January 2016, with 17 goals, which also aimed at achieving affordable and clean energy for all [4]. The government of India, under the SDG's India Index, is planning to deliver a complete view on the "social, economic, and environmental status of the country". The National Institution for Transforming India (NITI), shortly referred to as NITI Aayog, started a broad exercise to measure the progress of "India and its States towards the SDGs for 2030" [5]. As of 2010, the global power production from non-hydro renewable energy resources accounted for about 3.3\%. The support from the new policies, there has been a growth in renewables, which increased to $5 \%$ by 2011 [6]. In the early days, most industrialized countries were considered as the roots of renewable energy innovation. However, in recent years, many developing countries, especially China and India, have become popular leaders in renewable energy use, as well as an innovation [7].

Considering India's current energy situation, it should decrease the emissions from the energy sector in the future and is expected to curb the rise in temperatures to below $2{ }^{\circ} \mathrm{C}$ by 2100 to support the global effect indicated in the Paris agreement [8]. About 44\% of India's rural households, i.e., 138 million, produce lighting through electricity, an efficient and reliable source of power. The remaining 55\% primarily use kerosene, an inefficient source and its price have also become costly [9]. The depletion of natural resources and increasing demand is ubiquitous in all states of India. There is a shortage of energy, and hence, it slows down India's industrial and economic growth. The erection of new conventional power plants is tendentious and on the other side, fossil fuels are draining. The per-unit capita consumption of energy in India is increasing rapidly because of the growth of the population and industries. The prevalent energy crisis in India and its vulnerability led to an increase in energy prices, which later triggered the interest to promote alternative sources of energy. Hence, the government is on the verge of looking at alternate sources of energy that are climate-friendly and abundant, such as solar energy, wind energy, biomass energy, geothermal energy, and hydro energy. The use of renewable energy (RE) sources rather than conventional energy sources, such as coal, nuclear etc., facilitates the sustainable pathways in the power generation sector. India is in need of providing a reasonable, reliable, and eco-friendly source of energy. Hence, it is crucial to use both renewable and non-renewable resources in an optimized way. To attain this goal, the governments of all states have chosen energy policies implying eco-friendly, clean, and renewable energy resources [10].

Among the global renewable energy markets, the Indian renewable energy market seems to be a popular one and is currently one of the largest renewable energy-based electricity producers. As per the recent statistics, the installed capacity of RE accounts for $20 \%$ of its peak power capacity, which was $73.35 \mathrm{GW}$ as of October 2018 [11]. Overall, among the renewable energy sources, the wind has the capacity of $34.98 \mathrm{GW}$ as of 30 October 2018 [12], along with a target for installation of solar of about $100 \mathrm{GW}$ by 2020 [13]. The installation capacity of biomass reached $9.54 \mathrm{GW}$ and the installed capacity of the small hydro-power reached 4.5 GW as of 30 October 2018 [12]. Ata global level, currently, India secured a 6th place position based on its total installed renewable power plant capacity. India has also set a target of 175 GW of electricity from RE sources by 2022, which implies that RE would be able to contribute a $40 \%$ share of total installed capacity [14]. However, the drivers for RE in India are different than to other countries due to socioeconomic characteristics, population density, economic growth, cultural diversity, and geographical locations. India has given much importance and focus has shifted to integrating RE into its energy policy, which became a champion by setting up a ministry in 1992 dedicated to alternative energy sources, which have the future. In the long run, many policy measures have been initiated and technologies adopted to promote renewable energy penetration. The country's energy capacity growth roadmap is sketched in Figure 1 [14].

The current energy policy in India is principally concentrated on improving the deficiencies of many ongoing energy projects that were established to meet energy demand. Also, it incorporates the initiatives that integrate climate-friendly RE sources to reduce dependencies on conventional fossil fuel-based energy resources. Recently, governments have taken initiatives that motivate the wind and solar markets in deploying new energy plants, including non-electricity driven applications. In the last decade, decentralized energy systems with RE sources have become emerging options. Moreover, the 
National Tariff Policy (NTP) [14] was amended in 2016 and according to it, power purchases are to be done based on competitive bidding. Also, the NTP aimed at promoting RE adoption at a faster rate.

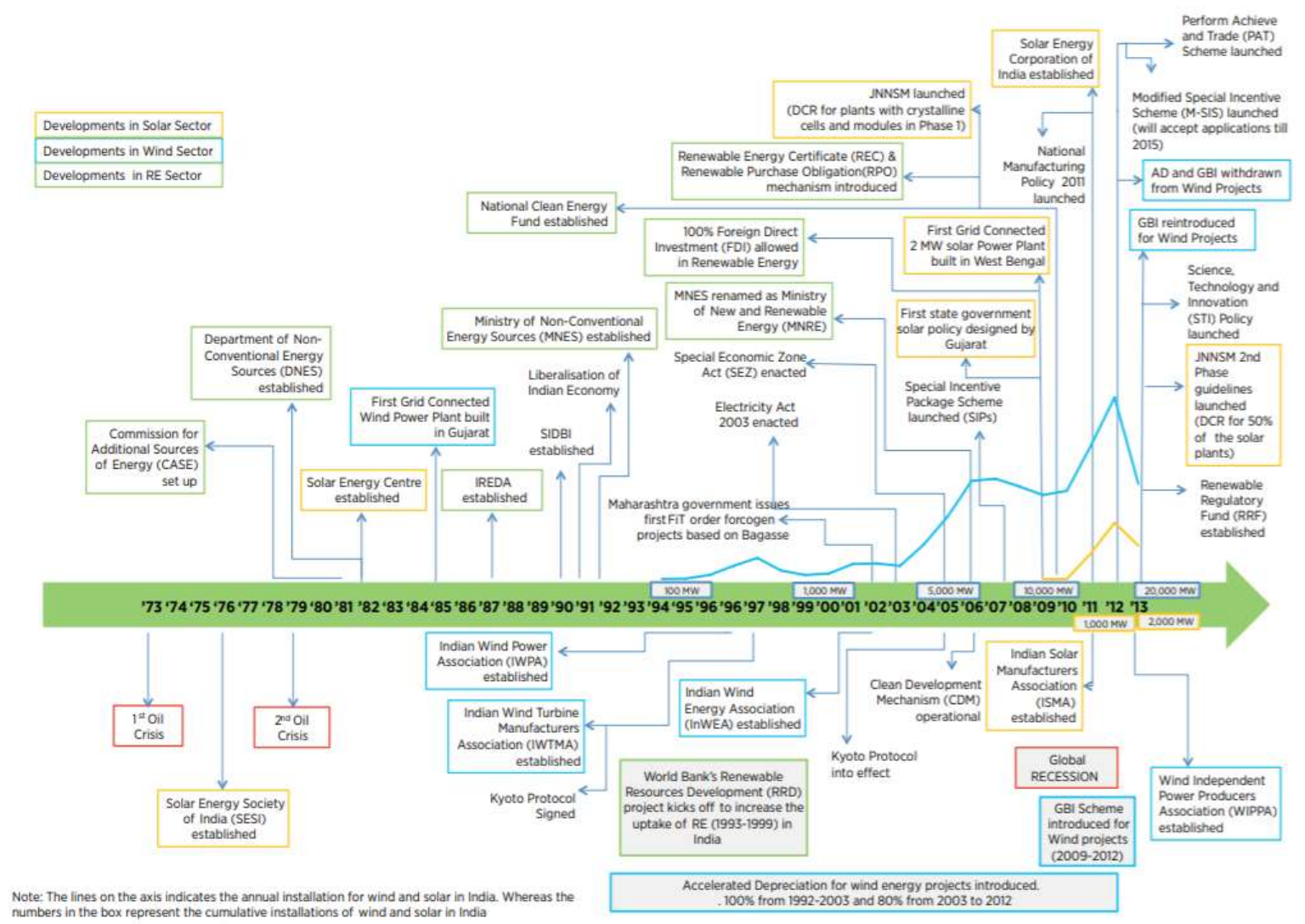

Figure 1. Renewable energy policy developments in India—a roadmap [14].

Among all the states of India, Gujarat, with a latitude of $23^{\circ} \mathrm{N}$ and longitude of $72^{\circ} \mathrm{E}$ [15], is one of the fastest advancing states with an area of $196,024 \mathrm{~km}^{2}$ [16]. Due to its geographical location, Gujarat is one of the most promising states in India in regard to RE potentialities and current RE generation capacity as it is higher than most other states in India. Alongside the central government, the Gujarat state government has also taken many initiatives over the last two decades to promote renewable energy contribution with the energy mix in the form of standalone and hybrid RE integrated systems. Moreover, policymakers, utilities, stakeholders, and researchers are working together to address the barriers to facilitate higher RE integration into the energy mix.

Therefore, the main aim of this study is as follows:

- To give an insight into the current energy scenarios of Gujarat, including the potentialities of renewable energy sources and the state's performance in utilizing RE sources so far in contributing to its socio-economic development.

- To explore the global and Indian current energy scenarios, potential, initiatives, and policy regulation to achieve sustainability in energy in order to meet the SDGs are explored. At the same time, existing frameworks, research projects, and literature publications were explored to identify suitable policy and framework options for Gujarat.

- Significantly, the limitations and barriers in the subsequent exploitation of non-conventional energy sources are explained, and specific guidelines are suggested for future researchers to overcome these barriers and to achieve their targeted goal in renewable energy resources.

This review will help future researchers, utilities, and stakeholders in implementing new RE integrated projects, not only in Gujarat but also in other states of India, as well as other places around the world. 


\section{Methodology}

A methodology based on an extensive literature study of the useful content available in various data sources was used. The following two types of content were considered mainly in this review article.

a. First and foremost were the publication databases that mainly contain peer-reviewed articles and conference proceedings. Besides, a few dissertations and related books are included. While searching for the literature, we used a few keywords considering the Boolean operators such as 'OR' and 'AND.' The following are websites we used:

- IEEE Explore

- Science Direct

- Scopus

- Google Scholar

b. The second information source was the data from the various technical reports and documentation on energy scenarios, energy policy, and guidelines of India, as well as Gujarat.

As a part of this state-of-the-art review, we came up with a few keywords after a detailed study on the concepts through an iterative process of study and a brainstorming session. Keywords used in this study are:

a. Global renewable energy scenarios; energy frameworks and research on power generation, both standalone and hybrid; renewable energy integrated systems;

b. Energy scenarios in India (energy generation and demand, availability of conventional and non-conventional energy sources, installed capacity of each of the sources, etc.);

c. Energy scenarios in Gujarat (energy generation and demand, availability of conventional and non-conventional energy sources, installed capacity of each of the sources, prospects of renewable energy sources, policy and framework, barriers and implications, etc.);

d. Energy policy (Global and Indian Energy Policy and Framework, Gujarat Energy Policy and Framework);

e. Generic items (global warming, global energy scenario, hybrid energy systems, grid-connected, and off-grid connected energy systems).

\section{Global Renewable Energy Scenario: Policy Framework and Current Status}

Energy is the critical enabler to SDGs, accelerates social progress, and enhances productivity by improving industrialization and living standards, which provides adequate education, healthcare, and water, in addition to reducing poverty and hunger [17]. Secure affordable and clean energy is critical. At present, the energy sector contributes to more than two-thirds of global greenhouse gas (GHG) emissions, which are responsible for extreme weather events as well as global warming. When compared to fossil fuels, renewable energy sources are pollution-free. Moreover, they are proven to be efficient both technically and environmentally [18]. Moreover, both access to energy and the growing energy crisis also directly affects economic growth, poverty, food production, education, health, clean water, well-being, and social security. The initial capital investment is very high, due to which the governments were facing problems in financing these projects. Considering the situation of developing countries, the struggle to offer capital funding and other subsidies is quite difficult $[19,20]$. On the other hand, financing options vary differently in urban areas as well as in rural areas. Hence, most rural areas do not have access to electricity, but in some situations, they might have stand-alone energy systems mostly run by diesel generators. Sometimes, these will be coupled with solar photovoltaic (PV). On the other hand, the world's electricity demand is excepted to grow by $70 \%$ by 2040, which introduces the energy crisis [4]. Moreover, energy cost is increasing day by day due to its increasing establishment costs. Therefore, it is an essential concern today to increase the renewable energy fraction into the energy mix with a smart grid infrastructure that can deliver efficient, reliable, and clean energy to 
society for a sustainable future. UNDP, government, utilities, stakeholders, and researchers are working together to harvest and integrate renewable energy sources with the energy mix to achieve reliable and affordable clean energy for all. UNDP's policy and action plan in reducing the energy access gap, increasing the RE share, and improving the rate of energy efficiency involves extensive support to national governments. UNDP extends support by "providing an inclusive package of technical assistance at the policy and institutional levels as well as on-the-ground investments ranging from local community-level support to nationwide efforts" [21].

Recently, significant initiatives have been taken to develop policies to increase renewable energy penetration into the energy mix. Over time, policies for renewable have been adopted as these are an essential component for addressing pertinent issues. Many policies have been adopted throughout the world in supporting renewables in the electricity sector, such as 61 countries introducing a feed-in tariff (FIT), and the introduction of green certificates or auction systems, with Europe leading implementation [14]. By 2017, policies for renewable power had spread to 121 countries. Many countries have initiated RE targets; for example, $20 \%$ of electricity will be supplied from RE sources in Australia by 2020 and $27 \%$ in Algeria by 2030 [21]. In spite of the fact that the distribution of non-conventional energy resources is significant, policies and the governmental actions framed by the government are significant in bringing updated technologies to public awareness [22-24]. As a part of awareness for having access to the governmental policies and their benefits, an approach known as "Footprint" is executed in European countries [25-29]. The integrated energy policy formulated by the government of India has covered all the sources of energy resources, including RE, which helps to develop energy supply options and to increase the exploitation of RE.

China is making significant efforts to harness the non-conventional energy resources effectively. Factors like the tariff, economic investments, work designs, and various other policies were studied and they seem to be primary drivers. On the other side, it was identified that non-conventional energy resources are beneficial, considering not only the climate change issue but also in helping to facilitate meeting the energy demand and reducing energy generation costs [30,31]. However, to implement such facilities and to attain the target and visions of non-conventional energy development, the significance of policies was focused upon, as they are essential for implementation [32-34]. On the other hand, the government of Bangladesh has taken several initiatives to utilize the energy from solar $\mathrm{PV}$ in addressing the energy crisis issues of a remote area [35]. One of the initiatives was the solar home system (SHS) that started in 2003 and the primary aim is to provide electricity in Bangladesh's remote communities. As per the statistics, the number of installed SHSs is around 4.12 million [36,37].

In order to access the future outlook, a multicriteria analysis was performed as non-conventional energy resources involve sophisticated technology for implementation $[38,39]$. The carbon storage cycle is a suitable development in energy storage techniques of non-conventional energy resources as it has excellent storage efficiency and storage density [40]. For a sustainable supply of renewable energy, the multicriteria analysis of the resources based on $\mathrm{CO}_{2}$ emissions, the cost of electricity, water, and land usage were performed [41]. Jamal et al. [42] proposed "a robust and universally convincing plan for remote area microgrids based on the multi-criteria decision-making approach" [42]. The study considered technical, social, economic, and environmental criteria and revealed that the economic criterion is the most critical factor compared to other factors.

The only main concern with the renewables is when a large-scale system is planned to integrate as they experience performance issues that are depended on weather parameters and location-specific climatic conditions [43]. Moreover, these alternative energy sources are still not economically competitive compared to conventional energy sources and solar energy, being the most intensive and reliable renewable energy source, and are available only for a few hours during the day. On the other hand, energy storage is still expensive and not a feasible solution at this stage $[44,45]$. Meeting energy demand only from renewable energy sources is not an attractive solution yet [45]. Therefore, to overcome these disadvantages in non-conventional energy production, hybrid systems are being developed, integrating both conventional and non-conventional energy resources. Many 
research outcomes available demonstrated the effectiveness of hybrid power systems compared to only conventional or only non-conventional energy systems. As a recent initiative, many tried to investigate the potential applicability of hybrid renewable energy networks. Few case studies are available for various weather conditions, and those can be found in [45-50]. Shafiullah et al. [45] came out with a "techno-economic model and load management systems", for the subtropical climate in Central Queensland, Australia, in which it was evident that hybrid power systems are economically and environmentally feasible and help utilities to manage the needs of a consumer efficiently. The role of energy management and the role of numerous possible strategies have been presented in [51]. In another study, by Hassiba et al., the team proposed an optimal operational strategy [52], while Saheb-Koussa [50] presented a wind/PV/diesel hybrid system for Algeria with battery backup. From these studies, it is understood that hybrid energy systems are the most suitable options. In a study by Dihrab and Sopian [48], they presented the performance of a hybrid energy system that is grid integrated. The study was conducted for three different areas in Iraq. Their results indicate that the proposed hybrid renewable energy system is capable of meeting the loads. However, it experiences the performance issues that are location specific. Later, many tried proposing the concept of a mini-grid for meeting energy loads of small range consumers. A few such projects conducted for Bangladesh location are discussed in $[53,54]$. Chowdhury et al. [52] indicated that the "mini-grid could be a useful tool to achieve the Sustainable Energy Access for All (SEforALL)" [55] goals as the proposed hybrid mini-grid system is technically and economically viable for Bangladesh.

From the literature, it can be concluded that, in most of the research cases, analyses were done based on techno-economic and environmental potentialities for integrating solar PV, wind, energy storage, and grid supply. Based on the overall research, it is apparent that the roles of a hybrid energy network, which may be a combination of renewable and non-renewable, are very crucial. These hybrid energy networks manage the peak demands and favor the overall electricity cost. However, the selection of hybrid energy network configuration is very crucial as it involves the active survey of energy sources. India has adopted many policies to ensure access to energy to all, considering the growing energy demand and domestic supply gaps. This also enjoys significant support from the political system and is recognized in the "Integrated Energy Policy (IEP)" [14]. The key factors, such as energy security and energy access to all, are given much priority. In order to reduce greenhouse gas emissions, RE has been recognized as a viable alternative and many RE projects have been initiated over the last decade to promote climate-friendly energy generation. India has a high potential for these new and renewable energy resources from diverse energy sources. Up to 31 March 2017, the total potential for renewable energy generation of the country was around 1,001,132 MW.

The solar power potential was about $649,342 \mathrm{MW}$ (share of $64.68 \%$ ), while wind potential was about 302,251 MW (share of 30.19\%) [56]. Gujarat has the potential for the generation of about $12.17 \%$ of total demand, which is the second-largest among the Indian states after Rajasthan in the case of solar, as of the date 31st March 2107 [57]. The non-urban areas that are yet to be electrified in India can be energized using hybrid non-conventional energy resources that are economical [58-60]. In [61], nine different combinations of RE sources have been investigated to explore the techno-economic and social viability issues. Among them, the micro-hydropower (MHP)-biogas-biomass-wind-PV-battery option offers the most suitable system. A hybrid energy source combining wind and solar energy was used in a rural village of Ethiopia, which satisfactorily played the role of a distributed generation system that served up to 200 households [62]. Singh et al. [62] stated that energy from only RE sources is expensive, while hybrid combinations of RE sources have more potential and can diversify India's remote area energy supply, which will serve to stimulate the Indian economy.

India has set $175 \mathrm{GW}$ as a tentative target for total RE generation that is to be achieved by 2022 [63]. In order to achieve the target, Indian governmental policies need to be strengthened to tackle the problems of policy uncertainty, availability of finance, quality of electrical transmission and distribution networks, and the financial status of the state electricity boards [14]. 
The practical implementation of policies and their impact would depend on the governance of the country. Ata global level, many countries have different policies, and considering the policies practiced in other countries may not be directly applicable to India [14]. India has gathered experience from other countries on how to accommodate feed-in tariffs, net metering, or financial support schemes. The schemes based on the learned experiences have helped to accelerate the implementation of suitable Indian policy options, and hence the share of renewable energy is increasing day by day. Moreover, both the central and state governments have taken initiatives related to the policy, which led India to play an instrumental role in achieving the renewable energy target. However, it remains an essential need to explore the current barriers concerning social, technical, and economic factors to harness RE in order to increase its integration into the energy mix. This review research explored the current renewable energy status of Gujarat as a case study, including the potential socioeconomic and technical barriers, and provides a set of recommendations to improve or remove the barriers that will enable increases of renewable shares to achieve the government RE target.

\section{Gujarat's Renewable Scenario-Current Status and Future Prospects}

Gujarat, a pioneer in energy, is surrounded by "Madhya Pradesh on the east, the Arabian Sea and the Pakistan province on the west, Rajasthan on the north and Maharashtra and the Union Territories of Diu, Daman, Dadra, and Nagar Haveli on the south" [64]. Even though Gandhi Nagar is the capital of the state, Ahmedabad is well-thought-out as the financial city in Gujarat and is its largest city. Gujarat has been a pioneer of energy production, contributing $9 \%$ of India's energy demand. The generation from renewable energy resources has increased from 5.6\% in fiscal year (FY) 2015-2016 to $9.2 \%$ during the year 2018-2019 [64].

India has one of the most attractive renewable energy markets in the world [65]. Gujarat contributed to 110,739 MW of renewable power generation during the year of 2017-2018, which contributed $26 \%$ of total state generation; this is one of the highest values in comparison to the values of other states in India. In the case of solar generation capacity of states, Gujarat stands fifth after Tamil Nadu, with an installed capacity of about $1587 \mathrm{MW}$ of solar projects [66]. Gujarat Electricity Regulatory Commission (GERC) has enhanced the Renewable Purchase Obligation (RPO), with the minimum power to be purchased from green energy resources rising from the current $10 \%$ to $17 \%$ in the next five years [63]. Renewable energy potential of various states in India is shown in Figure 2 [67]. The climatic characteristics of Gujarat play a significant part in deciding the most suitable renewable energy generation options, and thus knowing Gujarat's climate would be greatly beneficial. Gujarat experiences both tropical and subtropical steppe climates. The state also experiences occasional droughts and floods. Occasionally, cyclones occur along the coastline. 


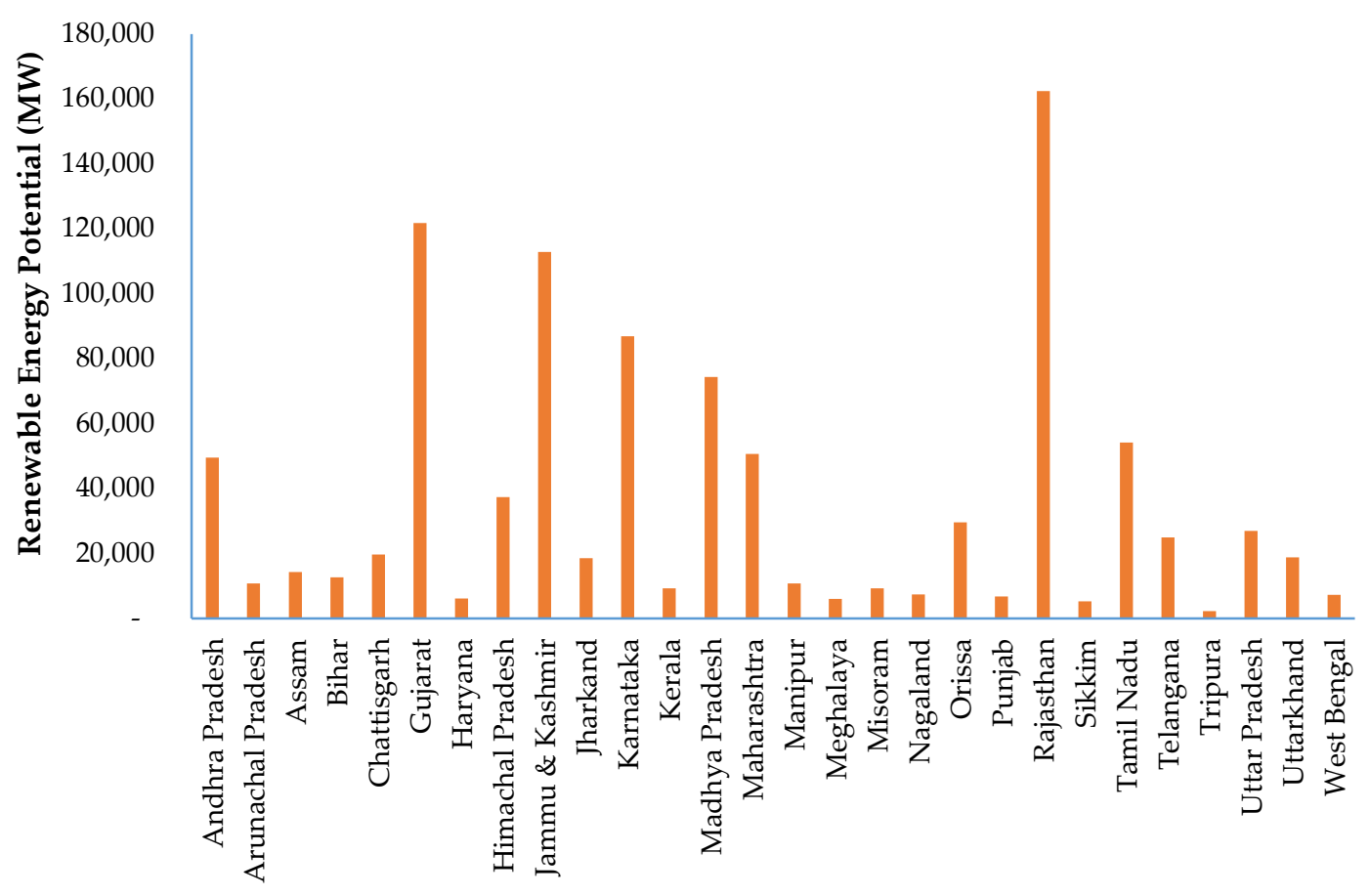

States in India

Figure 2. The renewable energy potential of various states (adapted from [67]).

\subsection{Wind Energy}

The average wind speed across the state was $4.7 \mathrm{~km} / \mathrm{h}$ during the year 2018 [68]. Surveys conducted have shown decent wind power potentials for establishing offshore wind turbines both on the west coast and the southern tip of the Indian peninsula. Gujarat shares 19.25\% (i.e., $6044 \mathrm{MW}$ ) of the total wind energy production in India, which is around 31,382 MW [69]. Aided by the quality of offshore wind, the private sector has also planned to install off-shore plants on the "Gujarat coast at the Gulf of Kutch" [70]. The Indian government has established a goal for achieving $5 \mathrm{GW}$ of offshore wind capacity by the end of 2022 and $30 \mathrm{GW}$ by 2030. The government plans to install $1 \mathrm{GW}$ capacity at the offshore of Gujarat. An expression of interest (EoI) for the country's inaugural offshore wind park at Gujarat was called in April 2018, which attracted 35 responses from domestic and international companies [71].

\subsection{Solar Energy}

India is rich in solar energy, with annual solar radiation of $200 \mathrm{MW} / \mathrm{square} \mathrm{km}$ and with the potential of solar power generation totaling $750 \mathrm{GW}$ [72]. In semiarid and arid regions like the western plateau of India, Gujarat and western coastal regions receive global irradiance of $5 \mathrm{kWh} / \mathrm{m}^{2} /$ day. Gujarat is one of the hotspots for solar energy generation, with annual global direct irradiance of $5.82 \mathrm{kWh} / \mathrm{m}^{2} /$ day [73]. The state and central governments took initiatives and installed solar plants of $1607 \mathrm{MW}$ capacity [74]. Gujarat contributes to $8 \%$ of India's total solar installations [75]. Sardar Sarovar Sangam Nigam Ltd. (SSNL) commissioned $10 \mathrm{MW}$ solar power projects on structures spanning over the top of canals and $15 \mathrm{MW}$ of canal bank power projects at Vadodara branch canal in September 2017. By 2022, Jawaharlal Nehru National Solar Mission (JNNSM) has planned to install 20 GW of solar power plants connected to the grid [76]. The airport of Ahmedabad installed a $700 \mathrm{kWp}$ rooftop solar plant as an initiative from the state government towards installing solar $[77,78]$. 


\subsection{Biomass Energy}

The potential assessment study carried out by the Ministry of New and Renewable Energy (MNRE) in Gujarat state indicated that the state has around $1014 \mathrm{MW}$ of biomass electricity potential and $350 \mathrm{MW}$ of electricity from bagasse using cogeneration [79]. The reason behind the possibility of biomass energy is due to the availability of various agro-feedstocks such as "stalks of mustard, juliflora, maize, dhaniya, soybean, cotton, tuver and sesame" [80]. The estimated availability of these resources found in the state is about 24 million tones [81]. As of 31 March 2016, biomass-based grid-integrated projects' peak capacity in the Gujarat state accounts for $41.10 \mathrm{MW}$. The main drawback causing the underutilization of biomass energy is that it is not available continuously for the whole year. The biomass from agriculture is available only during the harvesting period for two to three months in a year. Therefore, there is a need to store a significant biomass quantity for future use [82].

\subsection{Hydro Energy}

Gujarat has 185 river basins, but most of the river flows are concentrated in the relatively short monsoon season. With the considerable resource of water available, the state possesses the potential for hydel projects of 201.97 MW according to MNRE, whereas the projects currently installed are only 38.6 MW [83]. This state has only three major projects used for the production of hydroelectricity, and the state is concentrated more on the production of hydropower [84]. Sardar Sarovar Project has the Canal Head project of an installed capacity of 250 MW commissioned by SSNL [84,85]. In order to promote the usage of rivers and streams of Gujarat for clean energy production, the state introduced its Gujarat Small Hydel Policy in 2016 [86]. During the year 2018-2019, three projects were commissioned on Narmada Branch Canals by SSNL, with a total installed capacity of $31.2 \mathrm{MW}$ [87].

\subsection{Tidal Energy}

India's current tidal energy potential is around $8000 \mathrm{MW}$, as estimated by MNRE [88]. This is mainly because India has a long coastline that extends to about $7500 \mathrm{~km}$ "where the height of high tide is five meters ahead of the low tide", which helps in capturing a large amount of energy [89]. Of the total potential of India, the potential at the Gulf of Khambhat alone was found to be about $7000 \mathrm{MW}$ and potential at the Gulf of Kutch in Gujarat was found to be $1200 \mathrm{MW}$ [90]. These high values of potential in the state are mainly due to a maximum tidal range of about $11 \mathrm{~m}$ and $8 \mathrm{~m}$, with the current velocity reaching up to $3 \mathrm{~m} / \mathrm{s}$ at the Gulf of Kutch and the Gulf of Khambhat on the west coast [89].

\subsection{Geothermal Energy}

India has a vast potential for geothermal energy of around 10,000 MW [91]. Gujarat is the first state in India to be approved for the construction of the geothermal power plants at Dholera. Two geothermal bore wells were drilled at Dholera because the temperature was in the range of $47-50{ }^{\circ} \mathrm{C}$ [92]. The hot water obtained from the wells was used to generate power using the Organic Rankine Cycle (ORC) technique. This is the only active geothermal power station in India. The geothermal power has not yet been developed because the state and central governments of India do not have any suitable or favorable policies to develop these resources and require high investment costs compared to the non-renewable and other renewable sources. If the government of India implements beneficial policies, then the renewable resources can satisfy the total demand of the country, provided the government policies are used effectively and the renewable energy is developed up to its potential. 


\section{Lessons Learnt from the Literature on Gujarat's Renewable Energy Scenario}

\subsection{Recent Developments}

This section provides a summary of the recent developments in various renewable energy projects in the Gujarat state. Major developments during the years 2008-2018 are given. Also, the generation trend of various energy resources in Gujarat, along with an example, are presented in Table 1. 
Table 1. Major developments and policy on renewable energy in Gujarat.

\begin{tabular}{|c|c|c|c|}
\hline Resources & Developments During 2008-2018 & Installed Capacity Statistics & Example \\
\hline Wind & $\begin{array}{l}\text { - Between the years 2008-2009, the installation of wind projects has been increased by } \\
25 \% \text { in Gujarat, with an average increase of } 17 \% \text { in India. } \\
\text { - A remarkable growth in wind energy generation started with Oil and Natural Gas } \\
\text { Corporation (ONGC) Ltd. and established a } 51 \mathrm{MW} \text { wind plant in } 2008 \text {. } \\
\text { - The introduction of generation-based incentives for wind power producers in } 2009 \text { has } \\
\text { increased the investments in wind projects [93]. } \\
\text { - In 2010, GERC passed a second tariff order for wind energy generation and allowed } \\
\text { third party sales without cross-subsidy in the state [94]. } \\
\text { By } 2012 \text {, Gujarat had achieved the second-highest state-wise installed capacity of } \\
\text { - } 9666.88 \text { MW. } \\
\text { The state introduced a new wind energy policy in 2016, which entailed more private } \\
\text { sector investment for the development of the wind parks. } \\
\text { The government of Gujarat allocated land for a solar-wind hybrid park, which } \\
\text { encourages setting up } 3500 \text { MW of wind projects out of } 7000 \text { MW of projects by Solar } \\
\text { Energy Corporation of India Ltd., (SECI) [95]. }\end{array}$ & 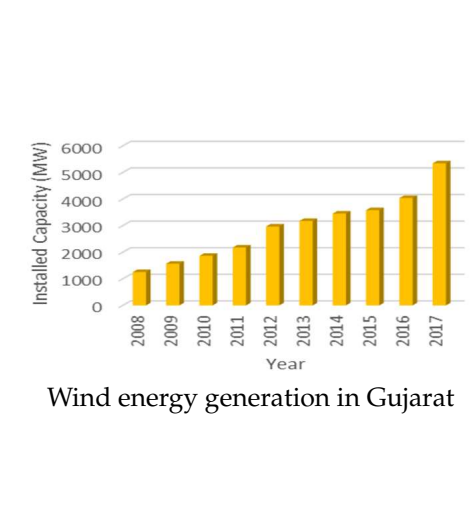 & $\begin{array}{l}200 \text { MW wind plant at Gulf of Khambhat, } \\
\text { Gujarat [20] }\end{array}$ \\
\hline Solar & $\begin{array}{l}\text { - Gujarat started its growth in solar power generation from } 2008 \text { after the revision of state } \\
\text { - In } 2009 \text {, Gujarat Solar Power Policy was revised, which led to a capacity addition of } \\
\text { - } 1000 \mathrm{MW} \text { [96]. } \\
\text { The introduction of JNNSM in } 2010 \text { significantly increased solar projects in Gujarat. } \\
\text { JNNSM approved the installation of } 365 \mathrm{MW} \text { capacity in Gujarat. Further, it approved } \\
351 \mathrm{MW} \text { of concentrating solar panel projects in Gujarat [97]. } \\
\text { - In 2012, the installed capacity was } 604.89 \mathrm{MW} \text {, as the government of Gujarat (GoG) } \\
\text { initiated canal-top solar power projects on the riverbanks. } \\
\text { - Several rooftop solar schemes and programs were launched between the } \\
\text { - years 2012-2013. } \\
\text { In 2015, the state solar installed capacity was } 1000.02 \mathrm{MW} \text {, and Gujarat contributed } 23 \% \\
\text { of total rooftop solar projects in India. } \\
\text { In 2018, the installed capacity of solar projects in Gujarat had reached } 1766 \mathrm{MW} \text { as of } 31 \\
\text { October, with the successful framework of policies at the state and national level for } \\
\text { solar projects [98]. }\end{array}$ & 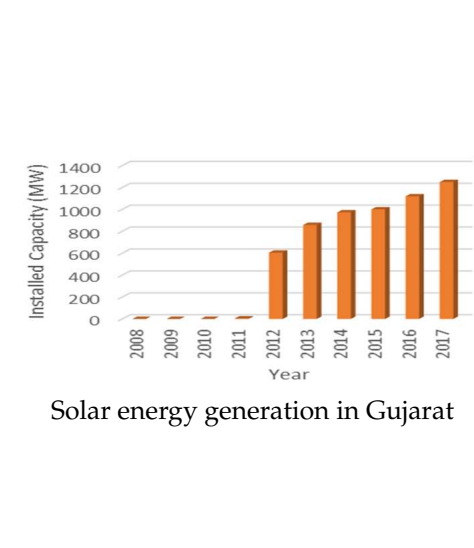 & $\begin{array}{c}\text { MW Sardar Sarovar Canal Top Solar } \\
\text { Project, Gujarat [78] }\end{array}$ \\
\hline
\end{tabular}


Table 1. Cont

\begin{tabular}{|c|c|c|c|}
\hline Resources & Developments During 2008-2018 & Installed Capacity Statistics & Example \\
\hline $\begin{array}{l}\text { Small } \\
\text { Hydropower }\end{array}$ & $\begin{array}{l}\text { - Gujarat has less share in hydropower in India. The state owns four major projects. } \\
\text { - The state government and private sector implemented several canal-based projects with } \\
\text { total installed capacity as } 779 \text { MW [84]. } \\
\text { The hydropower plants will take twice the time of solar or wind projects for } \\
\text { construction and commissioning. In particular, the Sardar Sarovar Dam on the } \\
\text { Narmada River in Gujarat took five years to construct [94]. } \\
\text { - The overall hydropower plant development has increased significantly during the 11th } \\
\text { Five-Year Plan period (2007-2012) in India, which was later stabilized. } \\
\text { MNRE provides central financial assistance (CFA) for hydro in both the public and } \\
\text { private sectors. } \\
\text { In 2016, Gujarat Small Hydel Power Policy was introduced to promote projects on } \\
\text { canals, rivers, and streams, and also to encourage private sector investment. This } \\
\text { increased the installed capacity to } 16.6 \mathrm{MW} \text { in 2017. }\end{array}$ & 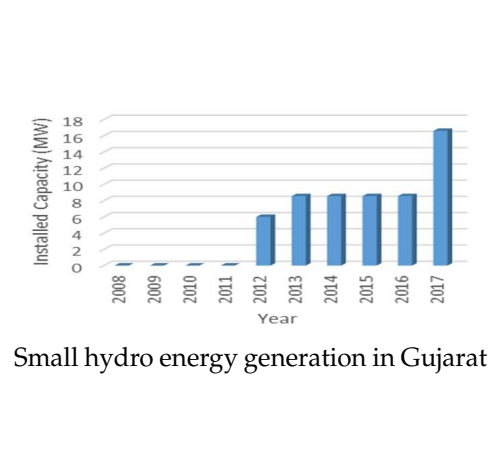 & 300 MW Ukai power plant, Gujarat [86] \\
\hline Biomass & $\begin{array}{l}\text { - Biomass energy potential is high in Gujarat [79]. } \\
\text { - In 2010, the GERC passed orders for the procurement of renewable electricity generated } \\
\text { by burning biomass at Ahmedabad. A capacity was installed for less than } 1 \text { MW for } \\
\text { production from biomass [99]. } \\
\text { - In 2013, the GERC passed an order for the procurement of power from biomass-based } \\
\text { power projects and bagasse-based cogeneration projects at Gandhinagar [100]. } \\
\text { In 2016, the government of Gujarat commissioned a policy on "waste to energy" for an } \\
\text { operational period of } 5 \text { years [100]. } \\
\text { In 2018, the MNRE introduced a few schemes that promote the use of energy efficiency } \\
\text { measures such as cogeneration using waste biomass, especially in sugar and other } \\
\text { related industries [101]. }\end{array}$ & 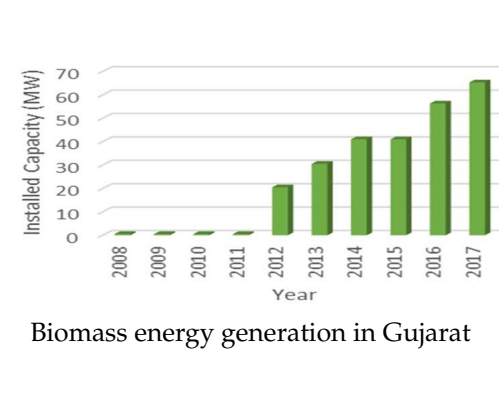 & 1.2 MW biomass plant at Sankheda, \\
\hline
\end{tabular}


In Table 1, the recent developments are given as per the renewable energy resources. These developments include the already commissioned power plants, projects that are under commissioning stage and the planned projects.

\subsection{Prospects and Implications}

Finally, through the lessons learned from the extensive policy and framework reviews and the literature surveys, key findings and implications were extracted for each of the available RE resources that help in prompting/deploying generation from those resources in Gujarat in the near future, and these are presented in Table 2. 
Table 2. Key findings and implications of renewable energy (RE) integration at Gujarat.

\begin{tabular}{|c|c|}
\hline Renewable Energy Type & Key Finding and Implications \\
\hline Wind Energy & $\begin{array}{l}\text {-Gujarat is one of the states in India to produce electricity from the wind in a larger amount [70]. } \\
\text {-Many private sectors are involved in the production of electricity from the wind due to the favorable policies by the central government and the state } \\
\text { government [70]. } \\
\text {-The potential of Gujarat for the offshore windmill is high. However, the interest shown by both central and state governments is not sufficient [65]. } \\
\text { Due to these reasons, private companies are not showing interest in the production of electricity from the off-shore windmill. } \\
\text {-If the central and state government of India come up with favorable policies for the offshore windmill, then a large amount of renewable power can be } \\
\text { generated by this renewable resource. } \\
\text {-Gujarat has refined the land policy for renewable projects recently, which seeks to set up wind parks in Gujarat in upcoming years [67]. }\end{array}$ \\
\hline Solar Energy & $\begin{array}{l}\text {-The solar plant capacity planned to be installed by JNNSM does not meet the requirements of the National Action Plan on Climate Change (NAPCC). } \\
\text {-Gujarat provides gross metering and a feed-in tariff for rooftop projects [77]. } \\
\text {-Government of Gujarat with GEDA has implemented many solar projects, like installation of solar street lighting and standalone systems on main } \\
\text { roads and solar PV on rooftops and solar/LED- based traffic signals on main roads [103]. } \\
\text {-Gujarat government provides net metering rooftop solar grid-interactive systems; installing them will reduce the consumer's utility bill. } \\
\text {-Gujarat announced the Wind Solar Hybrid Power Policy in } 2018 \text { for optimal usage of land and grid, which will improve the production in } \\
\text { upcoming years. }\end{array}$ \\
\hline Biomass Energy & $\begin{array}{l}\text {-There are many plants as the waste from agriculture are used here to generate electricity [81]. } \\
\text {-The policies and the subsidy by the governments are favorable. Due to the available policies, the biomass generation is available in Gujarat to } \\
\text { some extent. } \\
\text {-However, the main reason for not developing the biomass is that the raw material is not available [82]. } \\
\text {-As the agricultural products are available for only } 2-3 \text { months, it can be operated only for that period [82]. }\end{array}$ \\
\hline Small Hydro Energy & $\begin{array}{l}\text {-Each small hydro plant has a maximum capacity of } 25 \mathrm{MW} \text {. Thus, few projects with lesser capacity will not meet the target generation [87]. } \\
\text {-The state government should provide its equity funding to the private sectors, thus encouraging the projects. } \\
\text {-The Indian government proposed a policy that would provide long-time loan repayment and lower interest and other incentives, which would bring } \\
\text { down the tariff for hydro projects [85]. } \\
\text {-The projects can further be improved when specific barriers like land acquisition, financing risks, and precise policy formulation are } \\
\text { adequately addressed. }\end{array}$ \\
\hline Tidal Energy & $\begin{array}{l}\text {-The potential of Gujarat for tidal energy is huge due to its geographical locations [88]. } \\
\text {-The state and central government do not show any interest, due to which there is no active tidal power plant in the country [88]. } \\
\text {-Due to the lack of policies as of today, no private sector is willing to invest in the tidal projects. If the government comes up with attractive policies, } \\
\text { then the private sector can be able to come up with a plan for generating energy from the tidal energy [88]. }\end{array}$ \\
\hline Geothermal Energy & $\begin{array}{l}\text {-The construction costs for a geothermal power plant will be around } 25 \% \text { higher when compared to the cost required for the construction of the other } \\
\text { power plants [91]. } \\
\text {-As no private sector has implemented this resource due to policy issues, there is only one power plant in the state, even though the country has a } \\
\text { potential of more than } 10,000 \mathrm{MW}[92] \text {. } \\
\text {-If the state encourages these resources through effective policies and subsidies, then the state, as well as the country, can attain more installed capacity } \\
\text { from this renewable resource. }\end{array}$ \\
\hline
\end{tabular}




\subsection{Intelligent Monitoring and Optimization Facility}

The government of Gujarat in 2004 established the State Load Dispatch Centre (SLDC) in order to ensure the power system operation. "SLDC is liable for managing real-time operations for grid control and dispatch of electricity within the state to ensure secure and economic operation" [104]. Some of the critical functions of SLDC are system operation and control, scheduling/rescheduling of generation, dispatch of loads, fault detection and restoration, and metering and data collection. A typical snapshot of SLDC control is presented in Figure 3. With time, SLDC has taken many initiatives to improve its capacity, not only by integrating state of the art technology, but also expanding its system based on the need for increasing load demands, network congestion, equipment replacement, or repair needs due to age and fault detection.

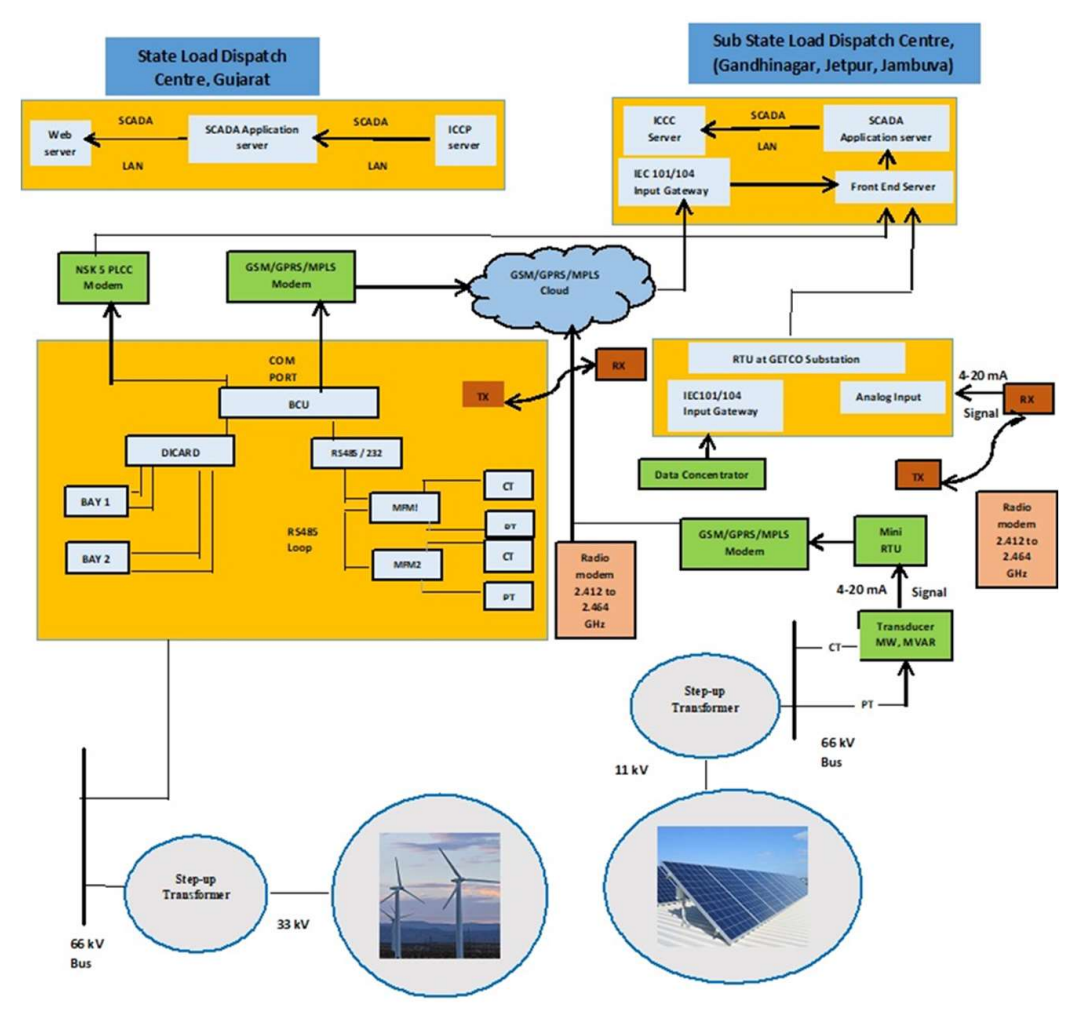

Figure 3. Real-time data capturing of renewable energy at State Load Dispatch Centre (SLDC), Gujarat (adapted from [105]). [Note: SCADA—supervisory control and data acquisition; LAN-local area network; ICCP—inter control center communications protocol; ICCC—integrated control and command center; GSM — global system for mobile; GPRS—general packet radio service; MPLS—multi-protocol label switching; RTU—remote terminal unit; MW—-megawatt; MVAR—mega volt-amps (reactive); kV—-kilovolts; GHz-gigahertz; IEC—international electro technical commission; PLCC—power line carrier communication].

SLDC currently uses intelligent tools to monitor the performance of the power systems network and helps to ensure efficient and reliable power delivery to the community. It not only provides real-time data information of its network condition, but also helps utilities by providing historical information about load growth, generation capacity, and generation trends from intermitted RE sources [104]. Figure 4 presents maximum demand in the last ten years that shows an almost linear growth in demand from which the state government and the utility can predict future load growth. Accordingly, utilities can identify their generation strategies to meet the load demand. Figure 5 shows that $26 \%$ of energy is generated from RE sources and also indicates the growth of RE generation from 2012-2018. 


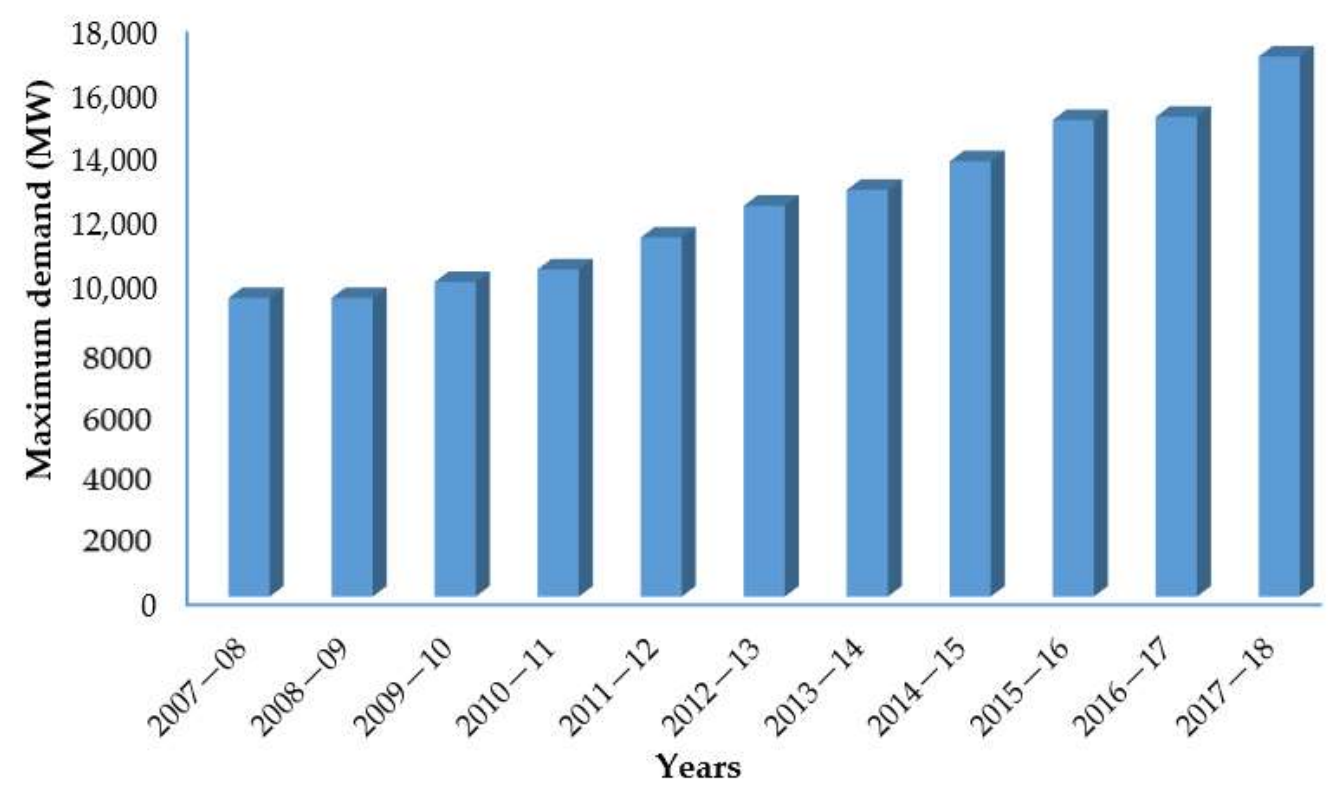

Figure 4. Maximum demand supplied in the 2007-2008; 2008-2009; 2009-2010; 2010-2011; 2011-2012; 2012-2013; 2013-2014; 2014-2015; 2015-2016; 2016-2017; 2017-2018.

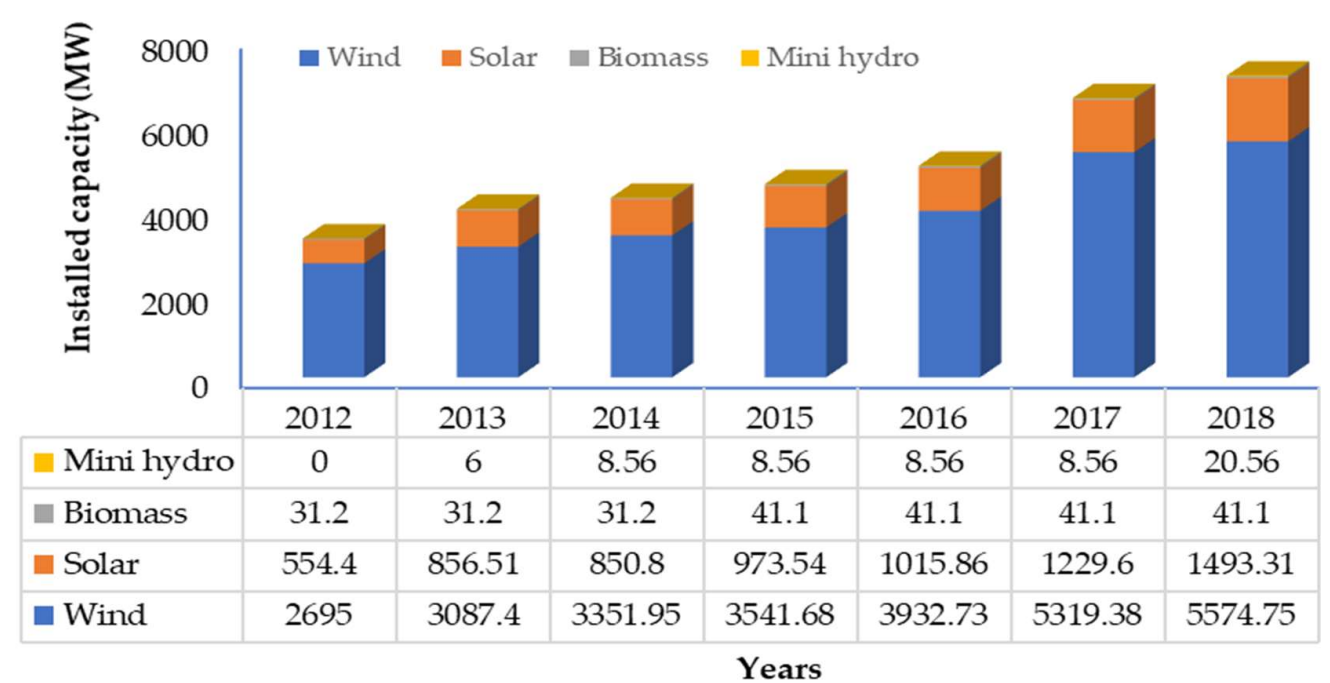

Figure 5. Installed renewable energy capacity.

Hourly wind and solar generation patterns during Fiscal Year FY 2017-2018 are shown in Figures 6 and 7 , respectively, in which it can be seen that generation from wind and solar varied randomly hour by hour. These data help utilities to identify their generation philosophy in order to run standby generators or energy storage systems, if available. SLDC not only helps utilities to identify their generation trends but also to identify power quality issues, in particular, voltage fluctuations and frequency variations due to large integration of RE into the grid. Figure 8 presents the number of days in a year that voltages were beyond $420 \mathrm{kV}$ in a few power stations at Gujarat, while the nominal voltage was only $400 \mathrm{kV}$. The monthly average frequency trend is shown in Figure 9. Therefore, this sophisticated state-of-the-art facility helps the Gujarat electricity sector to monitor, optimize, and control the power systems network in order to deliver efficient, reliable, cost-effective and sustainable power to the customer [104]. 


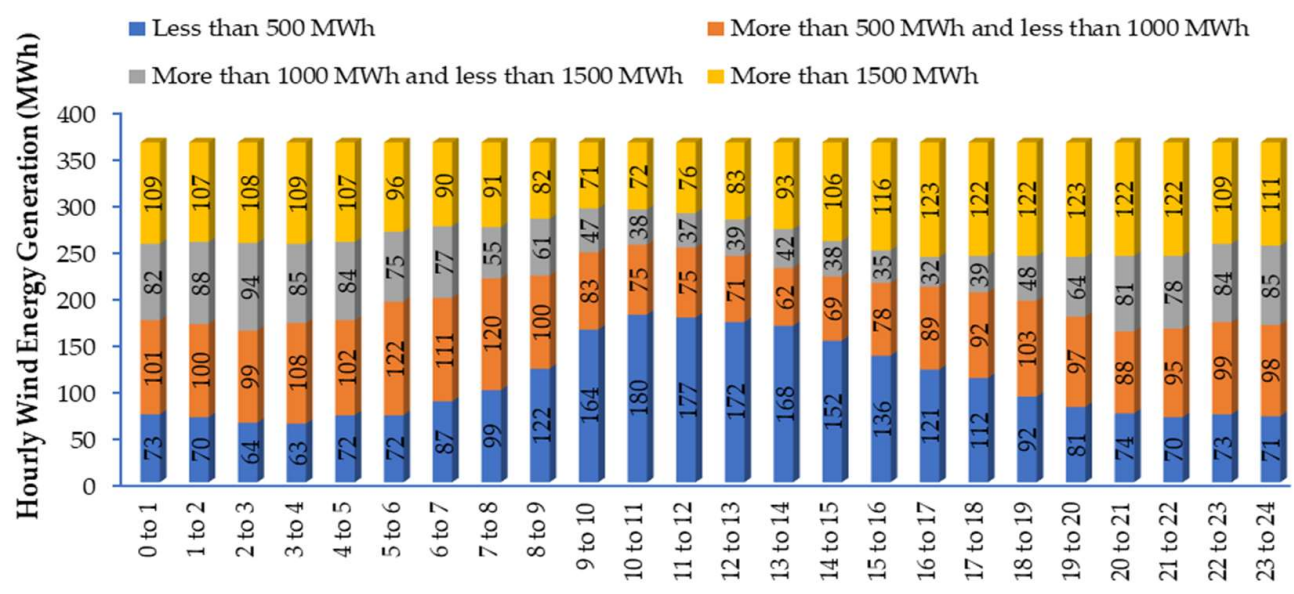

Hours

Figure 6. Hourly wind energy generation during Fiscal Year (FY) 2017-2018.

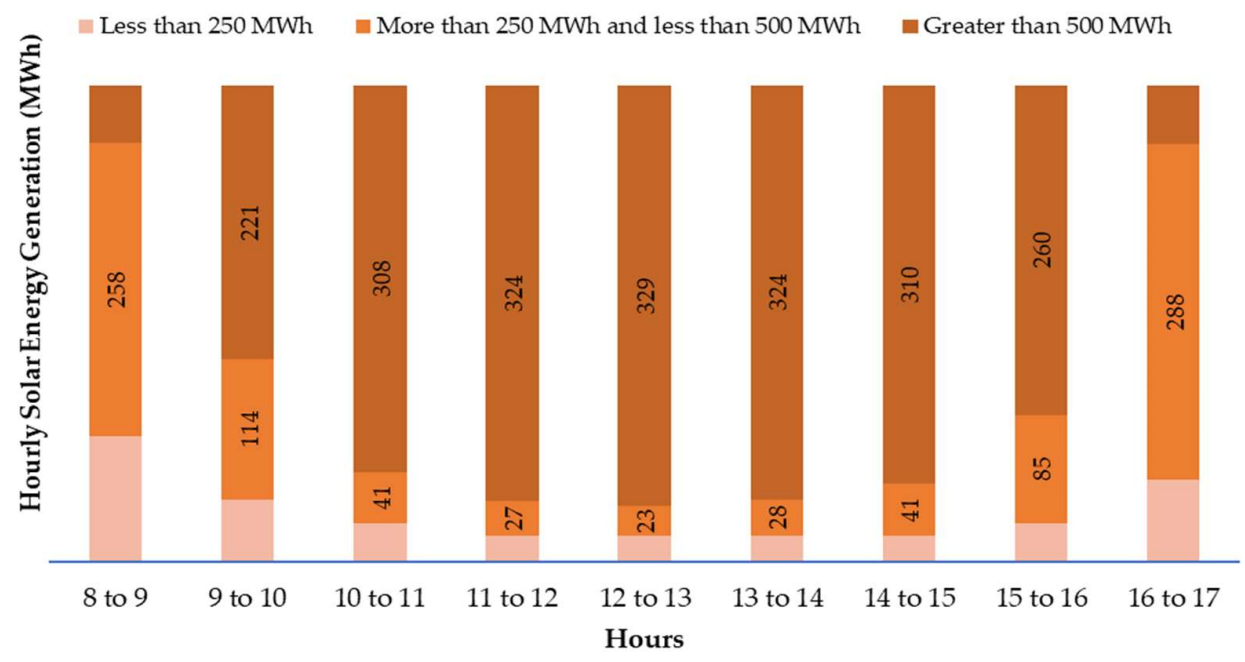

Figure 7. Hourly solar energy generation during Fiscal Year (FY) 2017-2018.

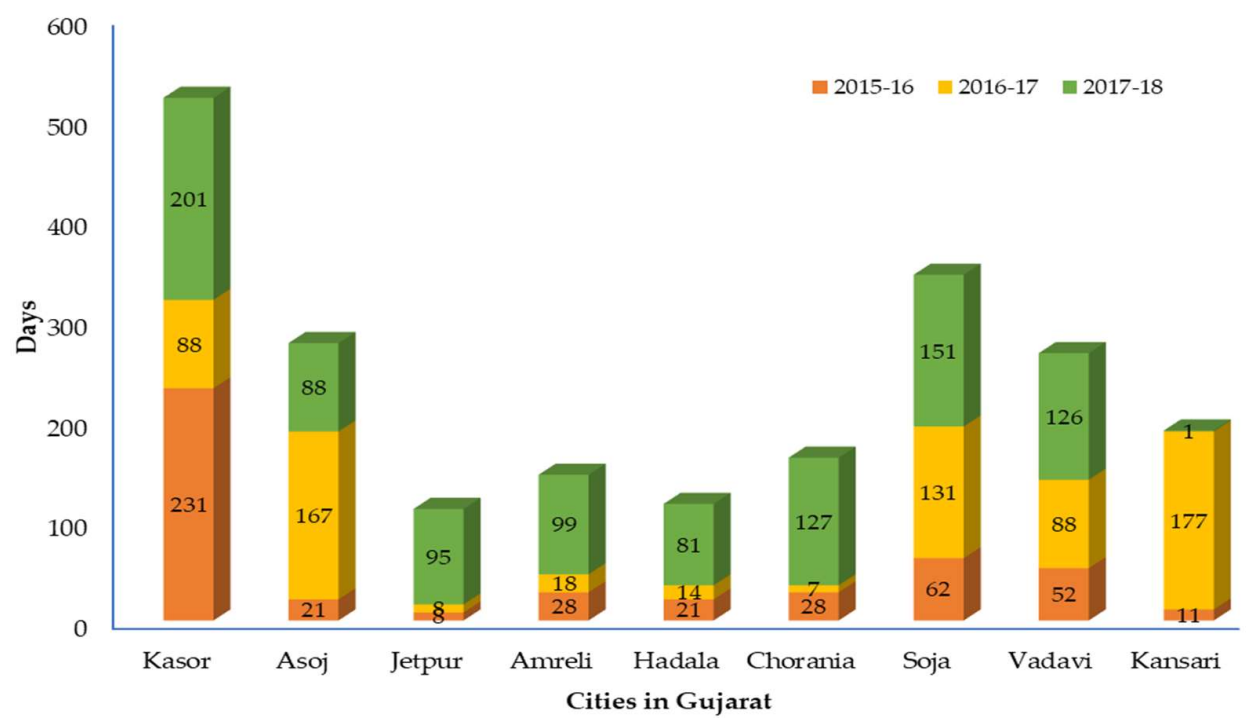

Figure 8. The number of day's voltage remained more than $420 \mathrm{kV}$. 


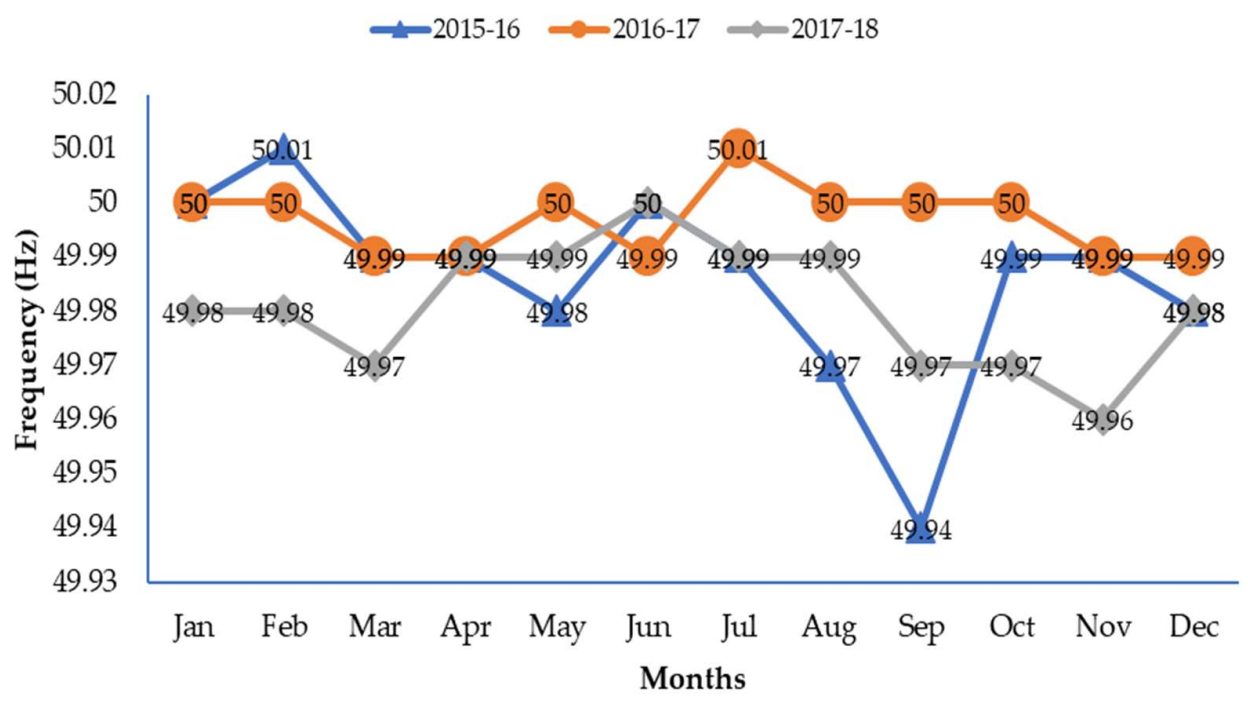

Figure 9. Monthly average frequency trend.

\subsection{Future Initiatives}

Deregulation has promoted several beneficial circumstances for RE production. Solar and wind are the leading RE sources in Gujarat, whereas tidal and geothermal are under development. The state has many plans for the advancement of RE generation. Planned projects have to be implemented properly in order to accomplish the targeted power by the end of 2022. The current and future installed capacity of RE resources as per MNRE's 2017 report was shown in Figure 10. Outcomes of key policy and planning undertaken by the Gujarat Government for meeting the RE integration targets are given below:

- Gujarat has set its target to install $22.6 \mathrm{GW}$ of electricity by 2022 from RE sources, where the current installed capacity is $7.6 \mathrm{GW}$ [107].

- The state has set a target to install $1000 \mathrm{MW}$ of solar and $2000 \mathrm{MW}$ of wind projects every year to meet the renewable purchase obligation (RPO) of $17 \%$ by 2022 [108].

- Old and conventional generation plants are to be phased out, and new plants with more capacity are to be installed [109].

- Gujarat has also outlined a plan for the next three years from 2019, under which the state will produce 15,000 MW energy, out of which 10,000 MW would be from solar and 5000MW from the wind. Thus, the state would increase the renewable energy generation to $53 \%$ of total energy production, where it is currently $28 \%$ [110].

- For encouraging wind and solar power projects, the state has introduced a wind-solar hybrid power policy 2018. Through this policy, the government is expected to produce 30,000 MW of energy by the year 2030 and the government will also provide wasteland for 40 -year leases to set up these hybrid parks [110].

- "Government of India has set a target to achieve $5 \mathrm{GW}$ of energy from offshore wind projects by 2020" [111].

- The government is to set up a 1000 MW mid-sea wind plant near Pipavav. Solar parks of 5000 MW at Dholera, $700 \mathrm{MW}$ at Radha Nesda, and $500 \mathrm{MW}$ at Harshad will also be developed [112].

- Small hydropower projects of installed capacity $53 \mathrm{MW}$ are under construction along the Canal of Narmada River through SSNM [87]. The state would produce 25 MW of power from small hydro plants by the year 2022, tentatively [113].

- The MNRE has a target of producing $288 \mathrm{MW}$ from biomass power by the year 2022 [113]. MNRE has taken initiatives to promote biomass power and bagasse cogeneration in the country. Waste to energy projects is also being set up to develop energy from industrial and agricultural waste. 
- Other upcoming large-scale projects are $700 \mathrm{MW}$ solar power park at Banaskantha district, $75 \mathrm{MW}$ solar PV power plant at Dhuvaran Thermal Power Station.

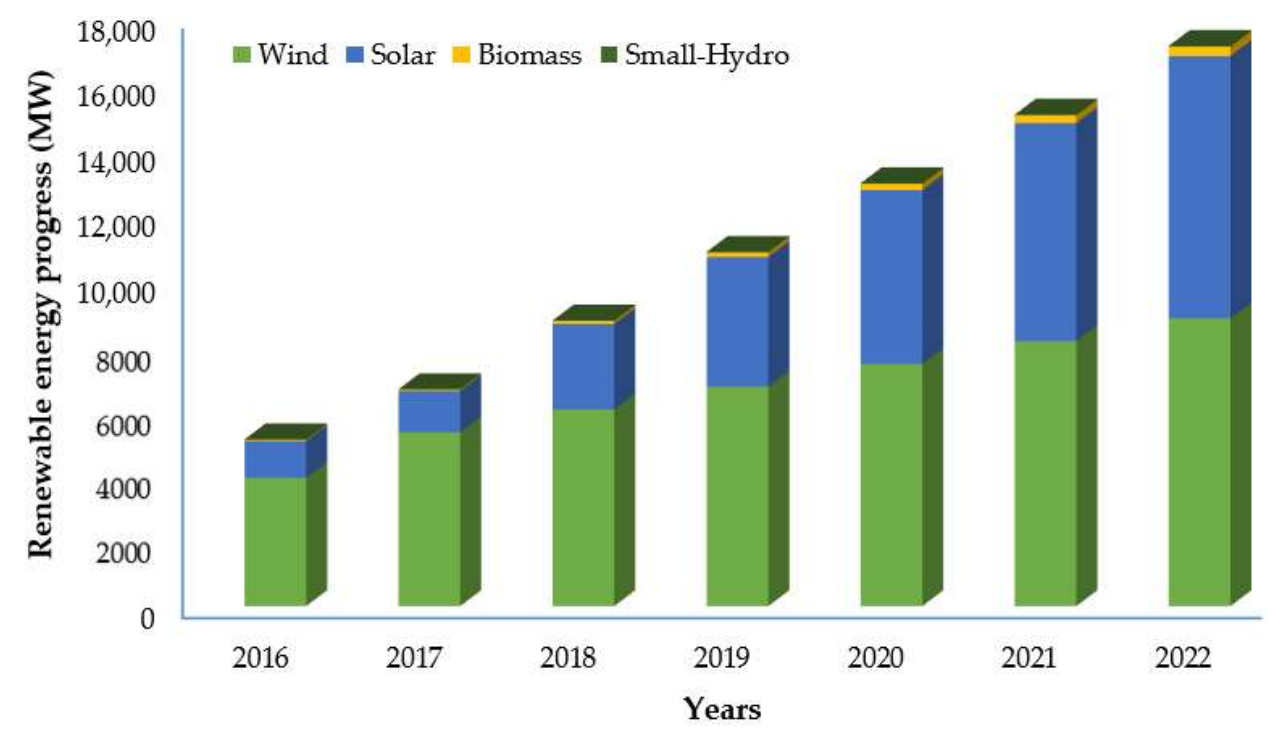

Figure 10. Developmental stages of renewable energy resources (Data source: 2017 Research Report on Energy Sector in Gujarat [106]).

It is evident that to increase the renewable energy contribution in the energy mix, the federal government of India and the state government of Gujarat have issued many policy guidelines, in particular, to increase electricity generation from solar, wind, small hydro, and biomass resources. The studied policies suggest the state's vision in a few areas, such as energy project development, an incentive for promotion, and measures for facilitation. Due to these policy implementations and initiatives, Gujarat is now one of the pioneer states in India that generates a significant amount of energy from RE sources and is almost at the stage of reaching their RE target. However, enormous opportunities are still available throughout the states that have not yet been fully explored. Barriers/constraints are the major reasons for not exploring and these barriers include political and social issues, availability of land space for RE plants, and financial and technical considerations regarding the regions requiring RE development.

\section{Practical Barriers and Recommendations}

Major barriers faced by power sectors in order to harvest large-scale RE sources and their integration into the existing energy network are presented in this section.

\subsection{Financial Barrier}

RE faces financial barriers due to a lack of awareness of the technology and the available resources. The electricity generation costs of these RE sources are high. These require higher capital investments initially based on the availability of suitable installation sites. As the capital costs for RE plants are high compared to the fossil fuel generation plants, there is a primary need for finding the ways that must be adopted. Adding to this, risks involving technology are high in RE projects as the technologies are still in development stages [114]. Bankers are reluctant to fund RE projects because they are non-tradable.

The various financial barriers faced in the development of solar included finance for the project, higher interest rates of about $12-15 \%$, long payback periods, and hence, the availability of bank funding only after the project was commissioned [106]. The various funding sources were provided through foreign financing, syndicate loaning, short-term loans, and bridge loans. Due to the elevated prices of the solar panels, they accounted for $50 \%$ of the total project cost, which leads to the absence of 
self-financing sources for project closure. Moreover, the generation through solar is most prominent compared to other ways of generation [115]. However, it is affected through the thermal losses which arise due to the variations in temperature. This can be reduced using anti-reflective coatings which in turn increases the overall cost [116].

The Indian Renewable Energy Development Agency (IREDA) plays a major part in the development of wind power projects. However, there is a need for developing financial institutions, particularly those backing the wind energy plants [117]. The various financial constraints faced by wind farms for their development [118] are high financial costs, volatile market, uncertain policy environment, lack of fixed interest rate loans, unavailability of long-term hedging instruments, uncertainty in financial markets, and availability of funds.

\subsection{Political and Policy Barriers}

A strong political stand is required in promoting the RE projects in both providing financial support as well as policy regulation. Some insufficient regulations or incentives encourage achieving renewable energy targets (RET) by industries or businesses. Moreover, the governments of India's policies lack tax benefits, subsidies for consumers, licensing requirements, etc. [117]. The Gujarat Solar Power Project (GSPP) 2009 also has a clause that states generated power can be sold only to Gujarat Energy Transmission Corporation Limited (GETCO) and not to any local grids, nor any buyers. This makes the power purchase agreement (PPA) non-tradable, and banks fund projects only if they are tradable [76].

\subsection{Institutional and Industrial Barriers}

Due to specific policy and financial limitations, the expected growth of RE is not observed in various institutions, particularly educational institutes, research centers, community activity centers, and hospitals. Risks for domestic investors are lack of negotiators, low credit ratings, land acquisition problems, etc. For foreign investors, off-taker risks, the lack of transmission facilities, and currency risks act as barriers for their investment [119]. Industries also faced challenges with a limited workforce when building the solar sector. It was not a huge problem, but it has to be acknowledged that there was a definite shortage of proficient personnel in the region [106].

\subsection{Land Availability Challenges}

Renewable energy plants require large areas, and this might cause deforestation of forest lands, thus causing threats to the wildlife or degradation of the coastal area, threatening tourism. Also, these systems have their influence on "land in terms of soil erosion", "damage to drainage channels", etc. [120]. Land acquisition is a key issue for the progress of RE plants. Lengthy endorsement procedures and the failure of the government to offer approvals to developers for infrastructure expansion is one of the important barriers [121].

\subsection{Market and Technology Barrier}

The green electricity generating companies are comparatively small, and available resources for small companies are therefore limited compared to large conventional energy generation systems [121]. Markets should be competitive in order to use resources effectively and to satisfy their preferences. However, on the other side, manufacturers may be unable to capture all the benefits and unwilling to provide detailed information on RETs, which is a barrier for the consumer market [122]. It is noticeable that advancing a grid-associated solar PV power plant in the state requires other logistics arrangements as the plant elements are already installed and commissioned [106]. For technologies like crystalline silicon technology and thin-film technology, the materials required are insufficient and they are imported from other countries. 


\subsection{Research and Development (RED) Cost Barrier}

$R \& D$ is essential in order to develop new technologies, new plants, and new generation capacity for Gujarat, which requires a significant investment. The number of research and development centers was limited, which affected new research progresses. Insufficient training institutes led to the absence of skilled labor [123] "Risk of innovation leakage and exploitation by competing markets puts pressure on the firms to invest for short-term returns" [124]. R\&D is also lagging because of the lack of collaboration among national and international organizations [125].

\subsection{Technical Barriers}

Most of the RE resources are dependent on seasonal variations and are also affected by location and time. Electricity generation potentials from the wind, and solar plants would mainly depend on weather conditions such as solar irradiance, temperature, humidity, and wind speed [126-128]. Hydro resources are available more during the winter season and less during summer, as the availability of water is much lesser in summer than winter. There is a clear mismatch between the energy output and the load, which results in energy loss. On the other side, there are large amounts of uncertainties in the energy network as the behavior of RE resources varied based on the location distance from load centers, and this introduces bidirectional power flows in the network. Moreover, the lack of digital machinery in existing networks puts the complete electricity network at risk. However, while integrating large-scale RE with the current power grid, we face many issues that need special attention. These issues include power quality (PQ), power factor, efficiency, energy conversion cost, operating cost, demand management, reliability, safety, security, and efficiency [43,129]. Major challenges observed concerning PQ in the power system network with RE integration are voltage and frequency deviation, harmonic injections, reactive power compensation, and active power control [130,131]. Renewable technologies also involve high risk as technologies are still in the development stage. For example, the solar PV technologies seems to be matured enough, but still risks due to failures, faults, and degradation are very high [132]. Overall, risks involving the technical side are not known and outcomes of the REs are uncertain. Manufacturing units are small and use conventional equipment. For spare parts or some raw materials, the country is still dependent on international suppliers [120].

\subsection{Overall Assessment of Barriers in Renewable Energy Resources}

The above-discussed barriers prevent the effective implementation of non-conventional energies in Gujarat. Based on the brief study carried out in this study, overall barriers related to renewable implementation in the Gujarat state are presented in Table 3.

Table 3. Barriers in integrating non-conventional energy resources into India's energy mix.

\begin{tabular}{ll}
\hline Renewable Energy Sources & Barriers \\
\hline & -Intermittent nature of wind. \\
& -Lack of promotion to the public about the benefit of wind plants. \\
& -High capital and installation cost and long payback period. \\
& -Lack of investment from the public and private sectors. \\
& -Regulatory uncertainty in investment. \\
& -Lack of strong support from the current wind energy policy \\
\hline & -Intermittent nature and available only for a few hours in a day. \\
& -Lack of knowledge about the overall benefit of installing solar plants \\
& -High upfront/installation cost, and long payback period. \\
& -Unawareness about the financial subsidy from the government for the installation \\
& of a solar plant. \\
& -Lack of marketing strategies and campaigns. \\
& -Political dependency and contradictory tensions for solar PV development \\
& -Issues related to spatial justice and the land politics \\
& -Effect of solar PV plants performance degradation on the economic gains \\
& -Reduction in power conversion efficiency with the increase in PV module \\
temperature based on ambient conditions.
\end{tabular}


Table 3. Cont.

\begin{tabular}{|c|c|}
\hline Renewable Energy Sources & Barriers \\
\hline Hydro [143-145] & $\begin{array}{l}\text {-Geographical location and rain dependency } \\
\text {-Lack of technology development and low efficiency. } \\
\text {-High upfront cost. } \\
\text {-Lack of regulations and related policies that mainly govern the progress of } \\
\text { small hydropower. } \\
\text {-High risk of dam failure. }\end{array}$ \\
\hline Biomass [146-148] & $\begin{array}{l}\text {-The installation cost is high, and it is not affordable for rural people. } \\
\text {-The lack of knowledge about the technology and high failure ratio. } \\
\text {-Underfeeding makes the biomass plant works unsatisfactorily. } \\
\text {-The wrong ratio of water and substrate is the leading cause of underfeeding. } \\
\text {-No proper technology for waste segregation. } \\
\text {-Lack of private investment. }\end{array}$ \\
\hline Geothermal [149,150] & $\begin{array}{l}\text {-The expenses of drilling the geothermal well are very high compared to oil } \\
\text { and gas wells. } \\
\text {-High risk of seismicity. }\end{array}$ \\
\hline Tidal [151] & $\begin{array}{l}\text {-High capital cost. } \\
\text {-Technology is at the deployment stage. } \\
\text {-Evacuation is tedious in islands and mangroves. } \\
\text {-Environmental impact on the marine ecosystem. }\end{array}$ \\
\hline
\end{tabular}

\subsection{Recommendations to Overcome Barriers}

- The government of India (GoI) must formulate action plans for the inclusive expansion of the RET sector. State governments should be consulted for formulating these action plans.

- GoI should pass RE laws to provide an inclusive legislative framework for all REs within a stipulated time.

- GoI must recommend appropriate standards and set a few benchmarks related to performance, durability, and reliability of various RETs for greater market penetration.

- So far, only 16 states have a renewable purchase obligation (RPO). States must set the RPO as mandatory within a suitable timeframe, failing which the Central Electricity Regulatory Commission (CERC) may determine the RPO for them [152].

- The GoI could best initiate financing possibilities and special fund allocation for RE projects. The role of insurance companies and other provident funds-related companies could be used to invest $10 \%$ of their portfolios into RE.

- RE should be made a priority sector to increase the funds available for the projects and lead to more extensive participation by commercial banks.

- To reduce the costs involving solar technologies, GoI should promote a core company to produce silicon and wafers.

- India, as well as Gujarat, should take the necessary steps to encourage research and development by setting up R\&D test centers and increasing investment in this sector.

- The cost of manufacturing should be reduced by framing policy and providing incentives to the stakeholders.

- Skill improvement training sessions on renewables to the interested people will promote RE generation in the future.

- Energy scheduling and the use of forecasting tools is very much essential. We recommend the grid operators to have control over the operating conditions and prior planning on the operation and maintenance of renewable-based power systems.

- Developing an appropriate design of the electrical equipment required for the grid integration of renewables. The control systems of an electrical circuit or the components mainly used for mitigating the fluctuations of voltage. The components related to power quality improvements with reactive power compensation are to be designed. Besides, the electrical circuits related to power factor improvements must be developed. 


\section{Conclusions}

Renewable energy harvesting and their integration into the energy mix is a crucial requirement for meeting the rapidly growing energy demands in an environmentally friendly manner. With renewable energies being one of the critical enablers of SDGs, the primary focus throughout the world is to increase their penetration with the current power systems. Accordingly, the United Nations, national governments, civil society, the research community, policymakers, and the private sector, as well as stakeholders, are working together for a sustainable energy system for the future. The energy demand in India is increasing gradually due to economic growth, as well as the rise in population. It will be more than double by 2030, which prompted the Indian Government to take major initiatives concerning policy-making and financial investments to harvest energy from climate-friendly renewable energy sources.

- Gujarat, one of the rising and most significant states in India, was selected as the case study for this research, which evaluated the renewable energy progress with an insight into the state's performance in utilizing renewable energy so far in contributing to the state's socio-economic development.

- Gujarat has an enormous renewable energy potential, in particular, wind, solar, and tidal energy resources due to its geographical location, which is climate-friendly and abundant.

- For meeting its energy demand, Gujarat needs to come up with new policies and guidelines to harvest its high potential for achieving the intended goal. Gujarat's government has already taken several initiatives to promote renewable energy generation by adopting improved policies and targeted financial investments.

- The Gujarat solar power policy in 2009 acted as a driving force by providing incentives to the developers. It acted as a significant development for grid-connected solar projects by utilizing the government's lands.

- Gujarat's new policies also emphasize rooftop projects to meet the target of $3.2 \mathrm{GW}$ installed capacity by 2022. Low tariffs for wind power projects invited significant investments in recent years.

- Gujarat's wind-solar hybrid power policy in 2018 helped to utilize the potential of both the resources, the policy provider's land, incentives, and waiver for cross-subsidy surcharge.

- The future renewable energy focus in Gujarat is on the offshore wind power plant, geothermal power plant, and tidal power plant.

- Investment-based renewable energy producers are well-inspired by the government of Gujarat to promote more potential industries and people. The government has also planned to set up research and development labs to test new technologies.

This study identified the limitations and barriers in facilitating renewable energy integration and provided guidelines with recommendations that the government, utilities, and stakeholders can use to overcome these barriers and to achieve their targeted goal. The government, policymakers, utilities, industrialists, local and international investors, stakeholders, and researchers can use the outcomes of this study as a useful guideline in their planning for deploying renewable integrated projects, not only in Gujarat but also other states of India, as well as other places around the world.

Author Contributions: All authors contributed equally to the final dissemination of the research investigation as a full article. All authors have read and agreed to the published version of the manuscript.

Funding: This research activity received no external funding.

Conflicts of Interest: The authors declare no conflict of interest. 


\section{References}

1. Manish, S.; Pillai, I.R.; Banerjee, R. Sustainability analysis of renewables for climate change mitigation. Energy Sustain. Dev. 2006, 4, 25-36. [CrossRef]

2. Shafiullah, G.M.; Amanullah, M.T.O.; Ali, A.S.; Jarvis, D.; Wolfs, P. Prospects of renewable energy-A feasibility study in the Australian context. Renew. Energy 2012, 39, 183-197. [CrossRef]

3. Shoeb, M.; Shafiullah, G.M. Renewable energy integrated islanded microgrid for sustainable irrigation-A Bangladesh perspective. Energies 2018, 11, 1283. [CrossRef]

4. UNDP Support to the Implementation of Sustainable Development Goal 7: Affordable and Clean Energy; United Nations Development Programme: New York, NY, USA, 2016; Available online: https://www.undp.org/ content/dam/undp/library/Climate\%20and\%20Disaster\%20Resilience/7\%20Clean\%20Energy-Feb\%202017. pdf (accessed on 13 April 2019).

5. SDG India Index-Baseline Report. NITI Aayog. 2018. Available online: http://niti.gov.in/content/sdg-indiaindex-baseline-report-2018 (accessed on 13 April 2019).

6. Patrick Narbel, A. What is really behind adoption of new renewable electricity generating technologies? Energy Sustain. Dev. 2013, 17, 386-390. [CrossRef]

7. Bayer, P.; Dolan, L.; Urpelainen, J. Global patterns of renewable energy innovation, 1990-2009. Energy Sustain. Dev. 2013, 17, 288-295. [CrossRef]

8. Rohit Gadre, G.A. Assessing the evolution of India's power sector to 2050 under different $\mathrm{CO}_{2}$ emissions rights allocation schemes. Energy Sustain. Dev. 2019, 50, 126-138. [CrossRef]

9. Hiremath, R.B.; Kumar, B.; Balachandra, P.; Ravindranath, N.H.; Raghunandan, B.N. Decentralised renewable energy: Scope, relevance and applications in the Indian context. Energy Sustain. Dev. 2009, 13, 4-10. [CrossRef]

10. Global Climatic Change; Council Foreign Relation (CFR): New York, NY, USA, 19 June 2013; Available online: https://www.cfr.org/report/global-climate-change-regime (accessed on 11 May 2018).

11. Malleswara Rao, L.; Rama Mohan, J.; Appa Rao, A.P.V.; Rama Krishna Rao, P.; Ramnarayana, K.; Sundar Singh, C. Present and Future trend of Renewable Energy in India. Res. Rev. Int. J. Multidiscip. 2019, $28-32$.

12. Power Sector in India. Available online: https://www.ibef.org/industry/power-sector-india.aspx (accessed on 22 November 2018).

13. Ministry of New and Renewable Energy (MNRE). 2018. Available online: http://pib.nic.in/PressReleaseIframePage. aspx?PRID=1555373 (accessed on 31 April 2019).

14. Renewable Energy. International Renewable Energy Agency. 2017. Available online: https://www.irena. org//media/Files/IRENA/Agency/Publication/2017/May/IRENA_REmap_India_paper_2017.pdf (accessed on 11 May 2018).

15. Location. Maps of India. Available online: https://www.mapsofindia.com/lat_long/gujarat (accessed on 27 May 2018).

16. Gujarat Information. Centre for Coastal Zone Management. 2017. Available online: http://iomenvis.nic.in/ index3.aspx?sslid=883\&subsublinkid=112\&langid=1\&mid=1 (accessed on 11 May 2019).

17. Santika, W.G.; Anisuzzaman, M.; Bahri, P.A.; Shafiullah, G.M.; Rupf, G.V.; Urmee, T. From goals to joules: A quantitative approach of interlinkages between energy and the Sustainable Development Goals. Energy Res. Soc. Sci. 2019, 50, 201-214. [CrossRef]

18. Shafiullah, G.M.; Carter, C. Feasibility Study of Photovoltaic (PV)-Diesel Hybrid Power Systems for Remote Networks. In Proceedings of the IEEE Innovative Smart Grid Technologies (ISGT) Asia Conference 2015, Bangkok, Thailand, 3-6 November 2015.

19. Shafiullah, G.M.; Oo, A.M.; Jarvis, D.; Ali, A.S.; Wolfs, P. Potential Challenges: Integrating Renewable Energy with the Smart Grid. In Proceedings of the Australasian Universities Power Engineering Conference 2010, Christchurch, New Zealand, 5-8 December 2010.

20. Offshore Wind Energy. Down to Earth. 2016. Available online: https://www.downtoearth.org.in/news/ gujarat-to-host-indias-first-offshore-wind-power-project-46784 (accessed on 27 May 2019).

21. Renewable Energy. International Energy Agency (IEA), 2018. Available online: https://www.iea.org/ policiesandmeasures/renewableenergy/ (accessed on 10 May 2019). 
22. Kanase-Patil, A.B.; Saini, R.P.; Sharma, M.P. Sizing of integrated renewable energy system based on load profile and reliability index for the state of Uttarakhand in India. Renew. Energy 2011, 36, 2809-2821. [CrossRef]

23. Gupta, A.; Saini, R.P.; Sharma, M.P. Steady-state modelling of hybrid energy system for off grid electrification of cluster of villages. Renew. Energy 2010, 35, 520-535. [CrossRef]

24. Kusakana, K.; Vermaak, H.J. Hybrid diesel generator/renewable energy system performance modelling. Renew. Energy 2014, 67, 97-102. [CrossRef]

25. Alonso, P.M.; Hewitt, R.; Pacheco, J.D.; Bermejo, L.R.; Jiménez, V.H.; Guillén, J.V.; Bressers, H.; de Boer, C. Losing the roadmap: Renewable energy paralysis in Spain and its implications for the EU low carbon economy. Renew. Energy 2016, 89, 680-694. [CrossRef]

26. Gallego-Castillo, C.; Victoria, M. Cost-free feed-in tariffs for renewable energy deployment in Spain. Renew. Energy 2015, 81, 411-420. [CrossRef]

27. Ortega-Izquierdo, M.; del Río, P. Benefits and costs of renewable electricity in Europe. Renew. Sustain. Energy Rev. 2016, 61, 372-383. [CrossRef]

28. Haas, R.; Resch, G.; Panzer, C.; Busch, S.; Ragwitz, M.; Held, A. Efficiency and effectiveness of promotion systems for electricity generation from renewable energy sources-Lessons from EU countries. Energy 2011, 36, 2186-2193. [CrossRef]

29. Hastik, R.; Walzer, C.; Haida, C.; Garegnani, G.; Pezzutto, S.; Abegg, B.; Geitner, C. Using the "footprint" approach to examine the potentials and impacts of renewable energy sources in the European Alps. Mt. Res. Dev. 2016, 36, 130-140. [CrossRef]

30. Dong, L.; Liang, H.; Gao, Z.; Luo, X.; Ren, J. Spatial distribution of China's renewable energy industry: Regional features and implications for a harmonious development future. Renew. Sustain. Energy Rev. 2016, 58, 1521-1531. [CrossRef]

31. Zhao, Z.Y.; Chen, Y.L.; Chang, R.D. How to stimulate renewable energy power generation effectively?-China's incentive approaches and lessons. Renew. Energy 2016, 92, 147-156. [CrossRef]

32. Gabriel, C.A.; Kirkwood, J. Business models for model businesses: Lessons from renewable energy entrepreneurs in developing countries. Energy Policy 2016, 95, 336-349. [CrossRef]

33. Engelken, M.; Römer, B.; Drescher, M.; Welpe, I.M.; Picot, A. Comparing drivers, barriers, and opportunities of business models for renewable energies: A review. Renew. Sustain. Energy Rev. 2016, 60, 795-809. [CrossRef]

34. Aslani, A.; Naaranoja, M.; Wong, K.F. Strategic analysis of diffusion of renewable energy in the Nordic countries. Renew. Sustain. Energy Rev. 2013, 22, 497-505. [CrossRef]

35. Renewable Energy. Sustainable and Renewable Energy Development Authority (SREDA), 2019. Available online: http://www.sreda.gov.bd/ (accessed on 10 May 2019).

36. Renewable Energy. Infrastructure Development Company Limited (IDCOL), 2014. Available online: http://www.idcol.org/2014 (accessed on 10 May 2019).

37. Shoeb, M.A.; Jamal, T.; Shafiullah, G.M.; Rahman, M.M. Innovative Smart Grid Technologies-Asia (ISGT Asia), IEEE. In Proceedings of the IEEE Innovative Smart Grid Technologies-Asia (ISGT-Asia), Melbourne, Australia, 28 November-December 2016.

38. Connolly, D.; Lund, H.; Mathiesen, B.V. Smart energy Europe: The technical and economic impact of one potential 100\% renewable energy scenario for the European Union. Renew. Sustain. Energy Rev. 2016, 60, 1634-1653. [CrossRef]

39. Gurkan, G.; Langestraat, R. Modeling and analysis of renewable energy obligation sand technology bandings in the UK electricity market. Energy Policy 2014, 70, 85-95. [CrossRef]

40. Gencer, E.; Agrawal, R. A commentary on the US policies for efficient large scale renewable energy storage systems: Focus on carbon storage cycles. Energy Policy 2016, 88, 477-484. [CrossRef]

41. Shmelev, S.E.; Van den Bergh, J.C. Optimal diversity of renewable energy alternatives under multiple criteria: An application to the, U.K. Renew. Sustain. Energy Rev. 2016, 60, 679-691. [CrossRef]

42. Jamal, J.T.; Tania, U.; Shafiullah, G.M.; Farhad, S. Using Experts' Opinions and Multi-Criteria Decision Analysis to Determine the Weighing of Criteria Employed in Planning Remote Area Microgrids. In Proceedings of the ICUE 2018 on Green Energy for Sustainable Development 2018, Phuket, Thailand, 24-26 October 2018.

43. Shafiullah, G.M.; Oo, A.M.T.; Shawkat Ali, A.B.M.; Wolfs, P. Potential challenges of integrating large-scale wind energy into the power grid-A review. J. Renew. Sustain. Energy Rev. 2013, 20, 306-321. [CrossRef] 
44. Arif, M.; Oo, M.T.; Amanullah, A.S.; Shafiullah, G.M. Impacts of Storage and Solar Photovoltaic in the distribution network. In Proceedings of the Australian Universities Power Engineering Conference (AUPEC 2012), Bali, Indonesia, 26-29 September 2012.

45. Shafiullah, G.M. Hybrid renewable energy integration (HREI) system for subtropical climate in Central Queensland, Australia. Renew. Energy 2016, 96, 1034-1053. [CrossRef]

46. Liu, G.; Rasul, M.G.; Amanullah, M.T.O.; Khan, M.M.K. Techno-economic simulation and optimization of residential grid-connected PV system for the Queensland climate. Renew. Energy 2012, 45, 146-155. [CrossRef]

47. Khan, M.; Iqbal, M. Pre-feasibility study of stand-alone hybrid energy systems for applications in Newfoundland. Renew. Energy 2005, 30, 835-854. [CrossRef]

48. Dihrab, S.S.; Ssopian, K. Electricity generation of hybrid PV/wind systems in Iraq. Renew. Energy 2010, 25, 1303-1307. [CrossRef]

49. Rehman, S.; Alam, M.M.; Meyer, J.P.; Al-Hadhrami, L.M. Feasibility study of a wind-pv-diesel hybrid power system for a village. Renew. Energy 2012, 38, 258-268. [CrossRef]

50. Saheb-Koussa, D.; Haddadi, M.; Belhamel, M. Economic and technical study of a hybrid system (wind-photovoltaic-diesel) for rural electrification in Algeria. Appl. Energy 2009, 86, 1024-1030. [CrossRef]

51. Baghdadi, F.; Mohammedi, K.; Diaf, S.; Behar, O. Feasibility study and energy conversion analysis of stand-alone hybrid renewable energy system. Energy Convers. Manag. 2015, 105, 471-479. [CrossRef]

52. Hassiba, Z.; Cherif, L.; Ali, M. Optimal operational strategy of hybrid renewable energy system for rural electrification of a remote area. Energy Procedia 2013, 26, 1060-1069. [CrossRef]

53. Chowdhury, S.A.; Aziz, S.; Groh, S.; Kirchhoff, H.; Filho, W. Off-grid rural area electrification through solar-diesel hybrid minigrids in Bangladesh: Resource-efficient design principles in practice. J. Clean. Prod. 2015, 95, 194-202. [CrossRef]

54. Bhattacharyya, S.C. Mini-grid based electrification in Bangladesh: Technical configuration and business analysis. Renew. Energy 2015, 75, 745-761. [CrossRef]

55. Sustainable Energy for All. 2019. Available online: http://www.se4all.org (accessed on 10 May 2019).

56. Future Scope of Renewable Energy. International Journal of Engineering and Research Technology (IJERT). 2019. Available online: https://www.ijert.org/research/present-status-and-future-scope-of-renewableenergies-in-india-IJERTV8IS020009.pdf (accessed on 11 May 2019).

57. Energy Statistics. Central Statistics Office. 2018. Available online: http://mospi.nic.in/sites/default/files/ publication_reports/Energy_Statistics_2018.pdf (accessed on 14 May 2018).

58. Chauhan, A.; Saini, R.P. Discrete harmony search based size optimization of Integrated Renewable Energy System for remote rural areas of Uttarakhand state in India. Renew. Energy 2016, 94, 587-604. [CrossRef]

59. Molyneaux, L.; Wagner, L.; Foster, J. Rural electrification in India: Galilee Basin coal versus decentralized renewable energy micro grids. Renew. Energy 2016, 89, 422-436. [CrossRef]

60. Chauhan, A.; Saini, R.P. Techno-economic feasibility study on integrated renewable energy system for an isolated community of India. Renew. Sustain. Energy Rev. 2016, 59, 388-405. [CrossRef]

61. Giday, G.Z. Hybrid renewable energy design for rural electrification in Ethiopia. J. Energy Technol. Policy $2013,3,38-52$.

62. Omveer, S.; Arif, I.; Sanjeev, K.; Saurabh, R.K. Hybrid renewable energy system integration in the micro-grid: Indian context. In Proceedings of the International Conference on Control, Computing, Communication and Materials (ICCCCM), Allahbad, India, 21-22 October 2016.

63. Policy. Business Standard. 2019. Available online: https://www.business-standard.com/economy-policy? time $=1558412049$ (accessed on 20 May 2019).

64. Solar Power Generation. MERCOM India. 2019. Available online: https://mercomindia.com/solar-powerincreased-34-yoy-q1-2019/ (accessed on 20 May 2019).

65. Projects. Gujarat Energy Projects (IBEF). 2019. Available online: https://economictimes.indiatimes.com/ industry/energy/power/gujarat-frames-land-policy-for-green-energy-projects/articleshow/67718088.cms? from $=$ mdr (accessed on 15 May 2019).

66. Annual Report. Gujarat Energy Transmission Corporation Ltd., 2019. Available online: https://www.sldcguj. com/compdoc/SLDC\%20Annual\%20Report_2017-18.pdf (accessed on 31 May 2019).

67. Renewable Energy Industry in India. India Brand Equity Foundation (IBEF), 2019. Available online: https://www.ibef.org/industry/renewable-energy.aspx (accessed on 15 May 2019). 
68. Surat. Weather Online, 2019. Available online: https://www.weatheronline.in/weather/maps/city?FMM= $1 \& \mathrm{FYY}=2016 \& \mathrm{LMM}=12 \& \mathrm{LYY}=2016 \& \mathrm{WMO}=42840 \& \mathrm{CONT}=$ inin\&REGION=0024\&LAND=IGJ\&ART $=$ WST\&R=0\&NOREGION=0\&LEVEL=162\&LANG=in\&MOD=tab (accessed on 11 May 2019).

69. Wind Power. Energy World, 2019. Available online: https://energy.economictimes.indiatimes.com/news/ renewable/indias-top-9-states-by-installed-wind-power-capacity/68782064 (accessed on 11 May 2019).

70. Offshore Wind Energy. Energy World, 2018. Available online: https://energy.economictimes.indiatimes.com/ news/renewable/india-announces-30-gigawatt-offshore-wind-energy-target-by-2030/64651102 (accessed on 11 May 2019).

71. Offshore Wind Pact with Denmark. Offshore Wind, 2019. Available online: https://www.offshorewind.biz/ 2019/04/15/india-approves-offshore-wind-pact-with-denmark/ (accessed on 11 May 2019).

72. Sharma, N.K.; Tiwari, P.K.; Sood, Y.R. Solar energy in India: Strategies, policies, perspectives and future potential. Renew. Sustain. Energy Rev. 2012, 16, 933-941. [CrossRef]

73. Gujarat. Synergy Enviro Engineers, 2019. Available online: http://www.synergyenviron.com/tools/solarirradiance/Ahmedabad\%252CGujarat\%252CIndia (accessed on 27 May 2019).

74. Solar Power Capacity. Energy World, 2019. Available online: https://energy.economictimes.indiatimes.com/news/ renewable/indias-top-10-states-by-installed-solar-power-capacity/68739456 (accessed on 11 May 2019).

75. Solar Park. Gujarat Power Corporation Limited, 2019. Available online: https://gpcl.gujarat.gov.in/showpage. aspx? contentid=15 (accessed on 11 May 2019).

76. Yenneti, K. Industry perceptions on feed in tariff (FiT) based solar power policies-A case of Gujarat, India. Renew. Sustain. Energy Rev. 2016, 57, 988-998. [CrossRef]

77. Rooftop Hurdles. Down to Earth, 2015. Available online: https://www.downtoearth.org.in/coverage/rooftophurdles-44171 (accessed on 20 May 2019).

78. Canal Top Project. Sardar Sarovar Project. Available online: https://renewablewatch.in/2019/03/08/sardarsarovar-narmada-nigam-proposes-develop-100-mw-canal-top-solar-power-project-gujarat/ (accessed on 27 May 2019).

79. Order No. 1. Gujarat Electricity Regulatory Commission, 2018. Available online: http://www.gercin.org/ uploaded/document/a9fbbb2c-47f9-4d34-bb35-bf0d67e131ca.pdf (accessed on 11 May 2019).

80. Gujarat Potential. Gujarat Energy Development Agency (GEDA), 2018. Available online: https:/geda.gujarat.gov. in/GEDA/2018/5/3/Gujarat\%20The\%20Renewable\%20Energy\%20Potential/6189 (accessed on 11 May 2019).

81. Anil, K.; Nitin, K.; Prashant, B.; Ashish, S. A review on biomass energy resources, potential, conversion and policy in India. Renew. Sustain. Energy Rev. 2015, 45, 530-539.

82. Biomass Sector in India. Bioenergy Consult. 2018. Available online: https://www.bioenergyconsult.com. /biomass-india/ (accessed on 11 May 2019).

83. Energy and Petrochemicals Department. Government of Gujarat. 2019. Available online: https://guj-epd. gujarat.gov.in/webcontroller/page/project (accessed on 16 May 2019).

84. Gujarat State Electricity Corporation Limited (GSECL). 2019. Available online: http://www.gsecl.in/index.php (accessed on 11 May 2019).

85. Hydro Projects Stalled. The Economic Times, 2016. Available online: https://economictimes.indiatimes. com/industry/energy/power/5950-mw-hydro-projects-stalled-policy-for-revival-on-the-cards/articleshow/ 67404406.cms (accessed on 11 May 2019).

86. Small Hydro. Saurashtra Canal Branch. Available online: https://3.imimg.com/data3/SX/MP/MY-4594437/ images-water_major_big_09-500x500.jpg (accessed on 27 May 2019).

87. Sardarsarovardam. Small Hydro Power Projects. 2019. Available online: http://www.sardarsarovardam.org/ fileman/Uploads/1.\%20DETAILS\%20OF\%20SHP\%20PROJECTS\%20March-19.pdf (accessed on 16 May 2019).

88. Power Generation. Gujarat State Electricity Corporation Limited (GSECL), 2019. Available online: http: //www.gsecl.in/index.php/business/powergeneration (accessed on 11 May 2019).

89. Tidal Energy in India. Market Express, March 2017. Available online: http://www.marketexpress.in/2017/03/ tidal-energy-in-india-7500-km-coastline-hidden-potential.html (accessed on 11 May 2019).

90. Satheesh-Kumar, J.; Balaji, R. Tidal Power Potential Assessment along the Gulf of Kutch, Gujarat, India. In Proceedings of the Asian Wave and Tidal Energy Conference (AWTEC) 2016, Singapore, 24-28 October 2016.

91. Gujarat Geothermal Project. Asian Power, 2013. Available online: https://asian-power.com/project/news/ gujarat-bids-india\%E2\%80\%99s-first-geothermal-power-plant (accessed on 11 May 2019). 
92. Geothermal Energy Ahmedabad. DNA India, 2019. Available online: https://www.dnaindia.com/ahmedabad/ report-gujarat-first-to-use-geothermal-energy-to-generate-power-2727154 (accessed on 11 May 2019).

93. Project. Sardar Sarovar Dam. 2019. Available online: http://www.sardarsarovardam.org/components-ofproject.aspx (accessed on 27 May 2019).

94. Sholapurkar, B.R.; Mahajan, S.Y. Review of Wind Energy Development and Policy in India. J. Energy Technol. Policy 2015, 2, 122-132. [CrossRef]

95. Gujarat Likely to Provide Land to Central Wind Projects. Economic Times, 2019. Available online: https://economictimes.indiatimes.com/industry/energy/power/gujarat-to-give-land-for-centreswind-power-projects/articleshow/68365227.cms?from $=$ mdr (accessed on 15 May 2019).

96. Pathak Minal, M.S. Gujarat State: Pioneering and Scaling up Solar Energy in India; Research Gate: Berlin, Germany, 2016.

97. Background Report for DIREC 2010. Indian Renewable Energy Status Report. 2010. Available online: https://www.nrel.gov/docs/fy11osti/48948.pdf (accessed on 15 May 2019).

98. Solar Installed Capacity. Gujarat Energy Development Agency, 2018. Available online: https://geda.gujarat. gov.in/Gallery/Media_Gallery/SPP_Details_as_on_31102018.pdf (accessed on 27 May 2019).

99. Order No. 5. Gujarat Electricity Regulatory Commission, 2010. Available online: https://geda.gujarat.gov.in/ Gallery/Media_Gallery/GERC_Order_5_of_2010_Biomass.pdf (accessed on 15 May 2019).

100. Order No. 4. Gujarat Electricity Regulatory Commission, 2013. Available online: https://biomasspower.gov.in/ document/programmeregulatory/Gujarat/Bagass\%20Tariff\%20Order\%20-\%20Order\%20No.\%204\%20of\% 202013.pdf (accessed on 15 May 2019).

101. Biomass Power Division. Ministry of New and Renewable Energy, 2018. Available online: https://mnre.gov.in/ sites/default/files/schemes/Schme\%20support\%20to\%20Biomass\%20\%282\%29_4.pdf (accessed on 15 May 2019).

102. Biomass Power. Gujarat Pipeline Project. 2013. Available online: https://www.undp.org/content/dam/ india/docs/pub-EnE/proceedings-of-workshop-on-romoting-adoption-of-biomass-power-t.pdf (accessed on 27 May 2019).

103. Future Plan. Government Energy Development Agency, 2018. Available online: https://geda.gujarat.gov.in/ geda/2018/7/20/Future\%20Plan/9263 (accessed on 20 May 2019).

104. Annual Report 2017-2018. State Load Despatch Centre Gujarat Energy Transmission Corporation Limited. Available online: http://www.sldcguj.com/compdoc/SLDC\%20Annual\%20Report_2017-18.pdf (accessed on 20 May 2019).

105. Gujarat. 3rd Meeting of CEA. 2017. Available online: http://www.cea.nic.in/reports/others/planning/resd/ 3rd_tech_comm_mom_050617.pdf (accessed on 27 May 2019).

106. Research Report. Energy Sector in Gujarat, 2017. Available online: http://www.gseb.com/DownloadFiles/ File/Research\%20Report\%20on\%20Energy\%20Sector\%20in\%20Gujarat.pdf (accessed on 20 May 2019).

107. Future Target. Times of India-Gujarat, 2019. Available online: https:/timesofindia.indiatimes.com/city/ ahmedabad/gujarat-to-add-15000mw-of-renewable-power-by-2022-minister/articleshow/67478906.cms (accessed on 3 June 2019).

108. 3k MW Renewable Capacity. Times of India, 2019. Available online: https://timesofindia.indiatimes.com/city/ ahmedabad/gujarat-to-add-3k-mw-of-renewable-capacity-every-year/articleshow/67389808.cms (accessed on 23 May 2019).

109. Gujarat Is a Power-Surplus State. Powerline, 2018. Available online: https://powerline.net.in/2018/07/20/ gujarat-power-surplus-state/ (accessed on 23 May 2019).

110. Renewable Energy in 10 Years. Gujarat Plans. 2019. Available online: https://www.iamrenew.com/policy/ gujarat-plans-produce-30-gw-renewable-energy-10-years/ (accessed on 23 May 2019).

111. Offshore Wind Capacity 2030. Economic Times, 2018. Available online: https://economictimes.indiatimes. com/industry/energy/power/government-aims-to-build-30-gw-of-offshore-wind-capacity-by-2030/ articleshow/64657334.cms?from=mdr (accessed on 23 May 2019).

112. Ahmedabad. Times of India, 2019. Available online: https:/timesofindia.indiatimes.com/city/ahmedabad/ music-history-replayed-with-kaushi-kanada/articleshow/67478892.cms (accessed on 23 May 2019).

113. Tentative State Wise Renewable Energy. Ministry of New and Renewable Energy. Available online: https://mnre.gov.in/file-manager/UserFiles/Tentative-State-wise-break-up-of-Renewable-Power-by2022.pdf (accessed on 23 May 2019). 
114. Tripathi, L.; Mishra, A.K.; Dubey, A.K.; Tripathi, C.B.; Baredar, P. Renewable energy: An overview on its contribution in current energy scenario of India. Renew. Sustain. Energy Rev. 2016, 60, 226-233. [CrossRef]

115. Elavarasan, R.M. The motivation for Renewable Energy and its Comparison with Other Energy Sources: A Review. Eur. J. Sustain. Dev. Res. 2019, 3, em0076. [CrossRef]

116. Rajvikram, M.; Leopanraj, S. A method to attain power optimality and efficiency in solar panel. Beni-Suef Univ. J. Basic Appl. Sci. 2018, 7, 705-708. [CrossRef]

117. Kulkarni, S.H.; Anil, T.R. Renewable Energy in India-Barriers to Wind Energy. Strateg. Plan. Energy Environ. 2018, 38, 40-69. [CrossRef]

118. Projects. Gujarat State Electricity Corporation Limited (GSECL), 2014. Available online: http://www.gsecl.in/ index.php/business/projects (accessed on 20 May 2019).

119. Vivek, S.; Kuldeep, S.; Gireesh, S. Reaching India's Renewable Energy Targets: The Role of Institutional Investors; Climate Policy Initiative: New Delhi, India, December 2016.

120. Nimish Kumar, N.P. The existence of barriers and proposed recommendations for the development of renewable energy in Indian Perspective. Environ. Dev. Sustain. 2018, 1-19.

121. Ansari, M.F.; Kharb, R.K.; Luthra, S.; Shimmi, S.L.; Chatterji, S. Analysis of barriers to implement solar power installations in India using interpretive structural modeling technique. Renew. Sustain. Energy Rev. 2013, 27, 163-174. [CrossRef]

122. Reddy, S.; Painuly, J.P. Diffusion of renewable energy technologies-Barriers and stakeholders' perspectives. Renew. Energy 2004, 29, 1431-1447. [CrossRef]

123. Elavarasan, R.M. Comprehensive Review on India's Growth in Renewable Energy Technologies in Comparison with Other Prominent Renewable Energy Based Countries. J. Sol. Energy Eng. 2020, 142, 030801. [CrossRef]

124. Marilyn Brown, A. Market failures and barriers as a basis for clean energy policies. Energy Policy 2001, 29, 1197-1207. [CrossRef]

125. Prabhu, G.N.; Narayanan, S.E.; Mathew, A. Evaluating the Future of Indian Solar Industry; Copyright of the Indian Institute of Management; An IIMB Management Review Initiative: Bangalore, India, 2008.

126. Shafiullah, G.M.; Oo, A.M.; Stojcevski, A.; Shawkat Ali, A.B.M. Integration of roof-top solar PV systems into the low voltage distribution network. J. Renew. Sustain. Energy 2014, 6, 033135. [CrossRef]

127. Shafiullah, G.M.; Oo, M.T.; Amanullah, A.S.; Wolfs, P. Experimental and simulation study of the impact of increased photovoltaic integration with the grid. J. Renew. Sustain. Energy 2014, 6, 033144. [CrossRef]

128. Rajvikram, M.; Sivasankar, G. Experimental study conducted for the identification of best heat absorption and dissipation methodology in solar photovoltaic panel. Solar Energy 2019, 193, 283-292. [CrossRef]

129. Jamal, T.; Urmee, T.; Calais, M.; Shafiullah, G.M.; Carter, C. Technical challenges of PV deployment into remote Australian electricity networks: A review. Renew. Sustain. Energy Rev. 2017, 77, 1309-1325. [CrossRef]

130. Suresh Kumar, U.; Manoharan, P.S.; Valan Rajkumar, M. Feasibility Sensitivity Analysis in Potential Area for Standalone Hybrid Renewable Energy in Tamil Nadu, India. Appl. Mech. Mater. 2014, 573, 757-766. [CrossRef]

131. Shafiullah, G.M.; Amanullah, M.T.; Oo, A.B.M.; Shawkat, A.P.W.; Mohammad, A. Meeting energy demand and global warming by integrating renewable energy into the grid. In Proceedings of the 22nd Australasian Universities Power Engineering Conference (AUPEC), Bali, Indonesia, 26-29 September 2012.

132. Rajput, P.; Malvoni, M.; Kumar, N.M.; Sastry, O.S.; Tiwari, G.N. Risk priority number for understanding the severity of photovoltaic failure modes and their impacts on performance degradation. Case Stud. Thermal Eng. 2019, 16, 100563. [CrossRef]

133. Thapar, S.; Sharma, S.; Verma, A. Key determinants of wind energy growth in India: Analysis of policy and non-policy factors. Energy Policy 2018, 122, 622-638. [CrossRef]

134. Sharma, S.; Sinha, S. Indian wind energy \& its development-policies-barriers: An overview. Environ. Sustain. Indicators 2019, 1, 100003.

135. Shreemat, P.; Shanker, S.V.; Naresh, G.; Vijayvergia, M.M.; Prakash Chandra, P.D. Determinants of success for promoting solar energy in Rajasthan, India. Renew. Sustain. Energy Rev. 2012, 359, 3-8.

136. Jolly, S.; Raven, R.; Romijn, H. Upscaling of business model experiments in off-grid PV solar energy in India. In Proceedings of the Conference Innovation and Sustainability Transitions, Kuala Lumpur, Malaysia, 9-11 January 2011; Asia at University of Malaya: Kuala Lumpur, Malaysia, 2011. 
137. Behuria, P. The politics of late late development in renewable energy sectors: Dependency and contradictory tensions in India's National Solar Mission. World Dev. 2020, 126, 104726. [CrossRef]

138. Sareen, S.; Kale, S.S. Solar 'power': Socio-political dynamics of infrastructural development in two Western Indian states. Energy Res. Soc. Sci. 2018, 41, 270-278.

139. Kumar, N.M.; Prabaharan, N.; Jerin, A.R.A.; Jayakumar, A. Impact of performance degradation and capital subsidy on the revenue of rooftop PV system. Int. J. Renew. Energy Res. 2019, 9, 128-136.

140. Yenneti, K.; Day, R.; Golubchikov, O. Spatial justice and the land politics of renewables: Dispossessing vulnerable communities through solar energy mega-projects. Geoforum 2016, 76, 90-99. [CrossRef]

141. Manju, S.; Sagar, N. Progressing towards the development of sustainable energy: A critical review on the current status, applications, developmental barriers and prospects of solar photovoltaic systems in India. Renew. Sustain. Energy Rev. 2017, 70, 298-313. [CrossRef]

142. Rajvikram, M.; Leopanraj, S.; Ramkumar, S.; Akshaya, H.; Dheeraj, A. Experimental investigation on the abasement of operating temperature in solar photovoltaic panel using PCM and aluminium. Solar Energy 2019, 188, 327-338.

143. International Hydropower Association. Hydropower and the World Energy Future Technologies and Program; International Hydropower Association: London, UK, 2000.

144. Esha, I.P. Small Hydropower for Developing Countries; European Small Hydropower Association: Brussels, Belgium, 2006.

145. Bhoi, R.; Ali, D.S.M. Potential of Hydro Power Plant in India and its Impact on Environment. Int. J Eng. Trends Technol. 2014, 10, 114-119. [CrossRef]

146. Mittal, S.; Ahlgren, E.O.; Shukla, P.R. Barriers to biogas dissemination in India: A review. Energy Policy 2018, 112, 361-370. [CrossRef]

147. Amar, K.K.; Sharma, D.; Meena, E. The Solid State Biogas Plant: A Boon for Water Scarce Areas Akshay Urja Ministry of New and Renewable Energy; Government of India: Delhi, India, 2016.

148. Rupf, G.V.; Bahri, P.A.; de Boer, K.; McHenry, M.P. Barriers and opportunities of biogas dissemination in sub Saharan Africa and lessons learned from Rwanda, Tanzania, China, India, and Nepal. Renew. Sustain. Energy Rev. 2015, 52, 468-476. [CrossRef]

149. Lund, J.W.; Sanner, B.; Rybach, L.; Curtis, R.; Hellstrom, G. Geothermal (ground-source) heat pumps a world overview. GHC Bull. 2010, 25, 10.

150. Harsh, K.; Gupta Sukanta, R. Geothermal Energy: An Alternative Resource for the 21st Century; Elsevier: Amsterdam, The Netherlands, 2007.

151. Anubhav, U. Tidal Energy: An Overview of Indian Scenario. Int. J. Adv. Res. Innov. 2018, 6, $44-46$.

152. Infrastructure Development Finance Company LTD (IDFC). Barriers to Developments of Renewable Energy in India and Proposed Recommendations. 2010. Available online: http://www.idfc.com/pdf/publications/ Discussion-paper-on-Renewable-Energy.pdf (accessed on 20 May 2019).

(C) 2019 by the authors. Licensee MDPI, Basel, Switzerland. This article is an open access article distributed under the terms and conditions of the Creative Commons Attribution (CC BY) license (http://creativecommons.org/licenses/by/4.0/). 